\title{
Challenging the Interline and Codeshare Legacy: Drivers and Barriers for Airline Adoption of Airport Facilitated Inter-Airline Network Connectivity Schemes
}

Jan Never and Pere Suau-Sanchez

\begin{abstract}
Network connectivity has always been under the sovereignty of airlines until a few years ago when a small number of airports embarked on challenging that legacy and introduced the first socalled airport-led transfer schemes. Although the viability and future of airport-led transfer schemes that entail an airport-airline-co-operation is heavily dependent on airline participation, their role and what could promote or impede their adoption decision is generally absent from academic literature. Therefore, this paper analyses the potential drivers and barriers for the airline adoption of airport facilitated inter-airline network connectivity schemes. In order to achieve this, a case study research strategy was employed and the triangulation of qualitative and quantitative data was attained through a combination of literature, interview and survey research that was guided by the innovation diffusion theory. Findings suggest a total of 23 key drivers and barriers that directly and indirectly influence the airline adoption of airport facilitated inter-airline network connectivity schemes. Beyond those individual drivers and barriers, three main research findings of strategic relevance for the future diffusion and airline adoption of such schemes can be identified: Limited awareness, divergent attitudes and the schemes obsolescence risk.
\end{abstract}

Keywords: Aviation; Self-connectivity; interline; codeshare; connectivity; airline; airport; innovation diffusion theory

JEL Codes: L93 Air transportation, R40 Transportation Economics: General, R41 Transportation Economics: Other, O32 Management of Technological Innovation and R\&D.

\section{INTRODUCTION}

The world's air transport industry has seen tremendous change in the post-deregulation era (Oum \& Park, 1997) but it was primarily the advent of the Low-Cost Carrier (LCC) business model (Ito \& Lee, 2003) and the emergence of the hub-and-spoke networks (Burghouwt, 2007) that shaped the dynamic and hyper-competitive airline industry landscape.

Designing powerful hub-and-spoke networks enabled airlines not only to build the so-called 'Network Fortresses' (Tretheway \& Waters, 1998), it simultaneously made airline partnerships more attractive as the spatial and temporal concentration of flights enabled efficient connectivity among the partners (Pels, 2001). This first manifested in strategic interline partnerships (Philips, 1987) and culminates today in multilateral and globe-spanning alliances and joint ventures (Seabury, 2015).

On the contrary, the emerging archetypical LCC business model was based on a strict Point-to-Point (P2P) regime without any network connectivity, not online and most certainly not interline with partners (Fageda et al., 2015). Through the unprecedented growth of these new breed of carriers, the amount and size of non-connected airline networks grew exponentially and some passengers began to self-connect those networks by purchasing separate tickets and handling the transfer themselves (Suau-Sanchez et al., 2017).

Almost 40 years after the airline deregulation first took off in the US (Doganis, 2010), these two key industry developments seem to converge as LCCs begin to signal their interest in network connectivity (de Wit \& Zuidberg, 2012) and airline partnerships (Morandi, et al., 2015). A noteworthy development in that respect is 
the emergence of so-called airport-led transfer schemes (Maertens et al., 2016a) which do have the potential to alter the airline industries' approach towards network connectivity and airline partnerships.

It was in the mid-2000s, when the first airports with a high volume of LCC traffic realised the potential of the non-connected airline networks at their doorstep and implemented innovative transfer schemes intending to facilitate the passengers' selfconnection (Maertens et al., 2016a). The very first two airport-led transfer schemes, 'viaberlin' and 'Cologne Bonn Connect', lasted only a few years. However, shortly after their discontinuance the current schemes at Milan-Malpensa (2011), Singapore (2012), London-Gatwick (2013) and London-Stansted (2018) were launched. While all four schemes share similar characteristics, they differ in one key aspect: airline participation. While 'ViaMilano' for instance operates independently from the airlines, 'GatwickConnects' entails an airport-airline-co-operation (Fichert \& Klophaus, 2016). Figure 1 shows the different types of airport-led transfer schemes and where this paper fits in terms of scope.

In 2017, easyJet announced their 'Worldwide by easyJet' platform which can be described as the next leap in the passenger self-connectivity evolution driven this time by an airline. The platform can be best described as a digital virtual hub that enables selfconnect and sales partnerships between easyJet and its participating carriers. EasyJet initially based their platform on the already developed self-connect itinerary identification technology of Dohop and the existing self-connect infrastructure of GatwickConnects (easyJet, 2017).

It was also in the mid-2000s, when the topic of self-connectivity and airport-led transfer schemes received first notable academic interest (e.g. Burghouwt, 2007; Grimme, 2008; Malighetti et al., 2008), although today the relevant literature is still sparse (SuauSanchez et al., 2016; Zeigler et al., 2017; Cattenao, 2017; Cserep, 2017) and mainly revolves around the potential and what implications it has for the airports. The potential implications for airlines have received very limited attention, which is somewhat surprising as network connectivity has always been under the sovereignty of the airlines and airport-led transfer schemes, at least to some extent, try to challenge that status quo.

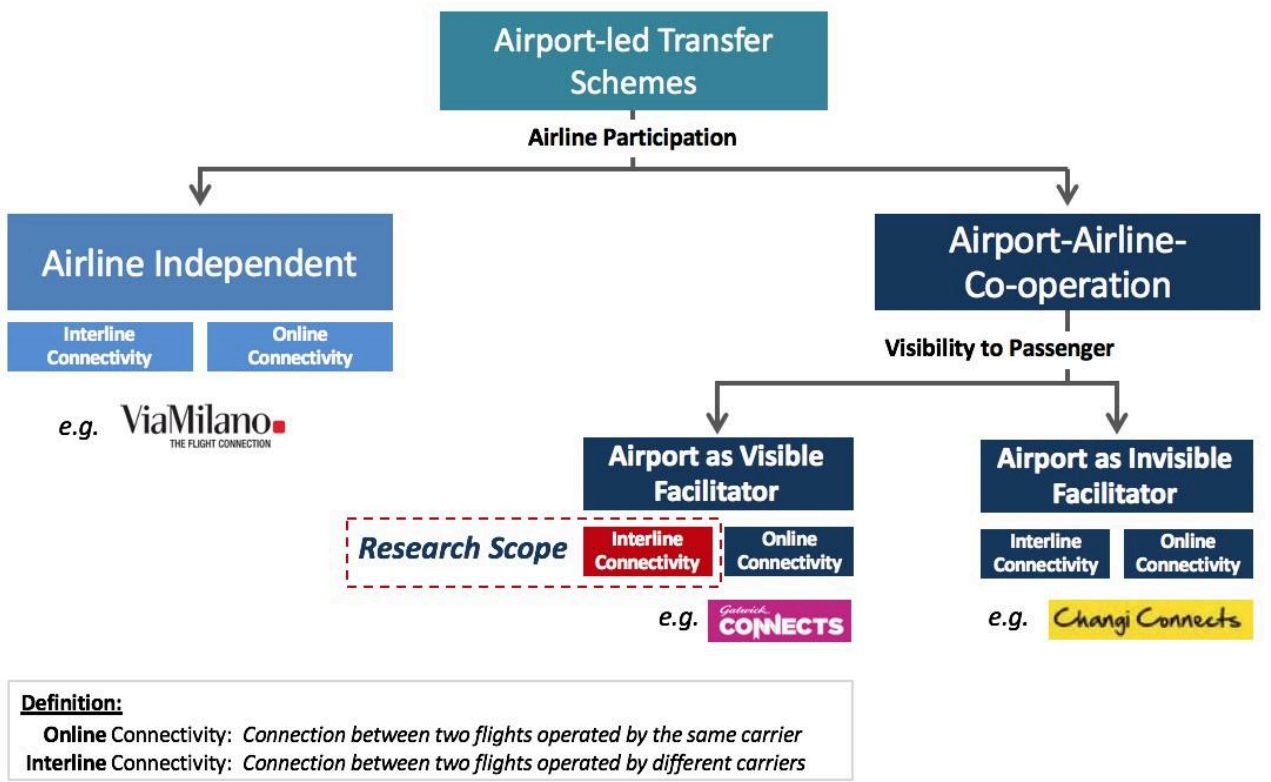

Figure 1. Types of airport-led transfer schemes and research scope. Source: Own elaboration. 
Although airport-led transfer schemes have been around for more than 10 years now, the concept is still innovative and only at the onset of its potential diffusion. In this regard, an innovation can add value to an airline if it either solves a major problem or creates a competitive advantage (Franke, 2007), both of which airport-led transfer schemes could potentially achieve with respect to online and interline network connectivity. The benefits an airline could potentially generate by adopting such schemes are somewhat similar to the benefits associated with traditional airline partnerships, for instance access to additional feed or an extended network reach (Bissessur \& Alamdari, 1998). Consequently, it can be argued that airport-led transfer schemes could challenge the legacy partnership mechanisms of interlining and codesharing, especially as they offer a solution to those carriers that do not connect today because of technological limitations or business model implications.

Hence, against this background, the focus of this paper is on interline network connectivity and in particular on how airport led-transfer schemes can act as an innovative partnership mechanism for airlines that do not connect today. As a consequence, and to stress our research focus, we introduce the term 'airport facilitated inter-airline network connectivity schemes' (AFINCSs) and use this instead of the more generic term 'airportled transfer schemes' where applicable.

While much has been written about traditional airline partnerships (e.g. Ginieis et al., 2012), little is known about what could actually promote or impede the airlines' adoption of airport-led transfer schemes to establish interline network connectivity. Beyond the overarching motivation to attract incremental passengers (Maertens et al., 2016a), only a few positive and negative aspects are sparingly mentioned in the academic literature, while a holistic understanding of potential drivers and barriers is clearly nonexistent. This is an obvious gap in the academic literature that requires further investigation as the viability and future of airport-led transfer schemes that entail an airport-airline-co-operation is heavily dependent on the airlines' participation. Thus, the aim is of this paper is to unveil, rank and assess the perceived drivers and barriers impacting the airline adoption of AFINCSs. In order to fulfil this aim we employ a mixedmethod approach. Firstly, we identify the drivers and barriers from the existing relevant literature as well as expert interviews. Secondly, we use a survey to collect intelligence on how industry professionals perceive the previously identified drivers and barriers.

The remainder of the paper is structured as follows: in Section 2 we review the literature on airline partnerships as well as the perspective of passengers, airports and airlines on airport-led transfer schemes. Section 3 presents the methods and the analytical framework we use for the analysis in order to reach our research objective. Section 4 then presents the results and Section 5 our conclusions.

\section{LITERATURE REVIEW AND STATE OF THE ART}

\subsection{Airline partnerships and legacy mechanisms}

Airline partnerships are for many airlines a key element of their strategy. Airlines cooperate because many customers demand a 'from anywhere to anywhere service' which is impossible for one airline to supply efficiently (IATA, 2012). Although the scope of, and reasoning for, cooperation in the early days of commercial aviation was different (Hall \& Eppink, 1992), in fact many bilateral air services agreements essentially forced the airlines to cooperate (Doganis, 1991), it can be argued that cooperation has always been a central element in air transport networks (Bissessur \& Alamdari, 1998). Modern forms of airline partnerships emerged in the early 1990s (Bilotkach \& 
Hüschelrath, 2010) and have evolved from rather simple agreements to complex and globe-spanning, multilateral partnerships (Doganis, 2010). At the heart of modern airline partnerships lies the motivation to connect to complementary partner networks to gain traffic feed and access to new markets (Burton \& Hanlon, 1994).

The emergence, growth and evolution of airline partnerships has attracted significant interest (Ginieis et al., 2012) which manifests in a vast amount of theoretical and empirical research covering the various facets of airline partnerships. Table 1 provides a non-exhaustive overview of perceived key research streams.

Table 1. Airline partnership research streams

\begin{tabular}{ll}
\hline Research streams & Selected publications \\
\hline Reasons for partnership & Bennet (1997); Burton \& Hanlon (1994); Evans (2001); \\
& Iatrou \& Oretti (2007) and Oum \& Park (1997). \\
\hline Partnership models & Fan et al. (2001); Gudmundsson \& Rhoades (2001); \\
& Henneman \& Malanik (2010) and Tretheway \& Oum (1992) \\
\hline Airline benefits & Hannegan \& Mulvey (1995); Iatrou \& Alamdari (2005); \\
& Min \& Joo (2016); Morrish \& Hamilton (2002); Oum et al. \\
& (2000) and Zou \& Chen (2017) \\
\hline Consumer benefits & Bilotkach (2005); Brueckner (2003); Goh \& Uncles (2003); \\
& Park (1997) and Weber (2005) \\
\hline Regulatory and anti-trust immunity & Bilotkach \& Hüschelrath (2012); Oum et al. (2001) and \\
& Whalen (2007) \\
\hline Network and connectivity & Bissessur \& Alamdari (1998); Dennis (2000) and Hsu \& \\
& Shih (2008) \\
\hline Revenue management & Belobaba \& Jain (2013); Vinod (2005) \\
\hline Brand & Chung \& Feng (2016); He \& Balmer (2006) and \\
& Kalligiannis et al. (2006) \\
\hline Low-cost carriers and partnerships & Fichert \& Klophaus (2016); Kawamori \& Lin (2011) and \\
& Morandi et al. (2015) \\
\hline Miscellaneous & Airline Service Quality: Tiernan et al. (2008) - Airport \\
& Terminal Co-location: Wu \& Lee (2014) - Frequent Flyer \\
& Programmes: Gudmundson et al. (2002) - Impact on firm \\
& value: Wassmer \& Meschi (2011) \\
\hline
\end{tabular}

Airlines, like any other commercial entity, have to make strategic choices across three different dimensions: the business strategy, the strategic directions and the strategy methods (Johnson et al., 2011). The latter dimension focuses on whether a company or airline pursues its strategy organically, through mergers and acquisitions (M\&A) or by entering into strategic alliances. Whilst organic development can be considered as the default method to pursue a strategy, M\&As are at the other end of the spectrum and requires taking ownership of another company or combining two independent companies. Strategic alliances lie somewhere in between those two methods and Oum et al. (2000, p. 5) describe a strategic alliance in the airline environment "as being a long-term partnership of two or more firms who attempt to enhance competitive advantages collectively vis-à-vis their competitors by sharing scarce resources including brand assets and market access capability, enhancing service quality, and thereby, improving profitability".

There are several external and internal drivers for cooperation. From an external point of view the patchy regulatory environment and the restrictive air service agreements create challenges for cross-border M\&As (Walulik, 2016). Since at the same time no individual carrier is able to satisfy the constantly growing demand for global air transportation airline partnerships are inevitable (Oum et al., 2000). The information revolution also impacted the airline industry on several grounds but the emergence of sophisticated Global Distributions Systems (GDSs) in the late 1970s (Humphreys, 1994) 
not only created strong distribution channels, it also made partnerships, in particular codeshare partnerships, an effective and attractive option for market entry (Evans, 2001).

There are also various generic internal reasons to cooperate: to achieve economies of scale, scope and learning; to gain access to other firms' assets, resources and competences; to reduce and mitigate risks through sharing; to shape competition; and to reach the market faster (Bennet, 1997; Evans, 2001). Beyond those generic reasons there are other specific internal motivations for cooperation between airlines: to enable or increase the interline passenger feed; extend the network reach; create a seamless travel experience; increase the marketability of interline itineraries through codesharing; improve frequent flyer programmes, mutually operate services, share facilities and jointly purchase supplies; and collectively schedule flights and influence pricing (Burton \& Hanlon, 1994; Bissessur \& Alamdari, 1998; Iatrou \& Oretti, 2007; Bilotkach \& Hüschelrath, 2012).

Although there are many good reasons to cooperate, it must not be ignored that implementing partnerships can be costly. According to Fageda et al. (2015) connecting passengers entails a series of consequences that have ramifications across the airline business competitiveness. In the context of airline partnerships, it must be acknowledged that complexity, risks and costs arise from negotiating, implementing, and coordinating the partnership. Figure 2 presents the complexity of the partnership implementation chain. This in fact is one of the key reasons why many LCCs have refrained from partnering, although it appears that lately this has started to change (Morandi et al., 2015).

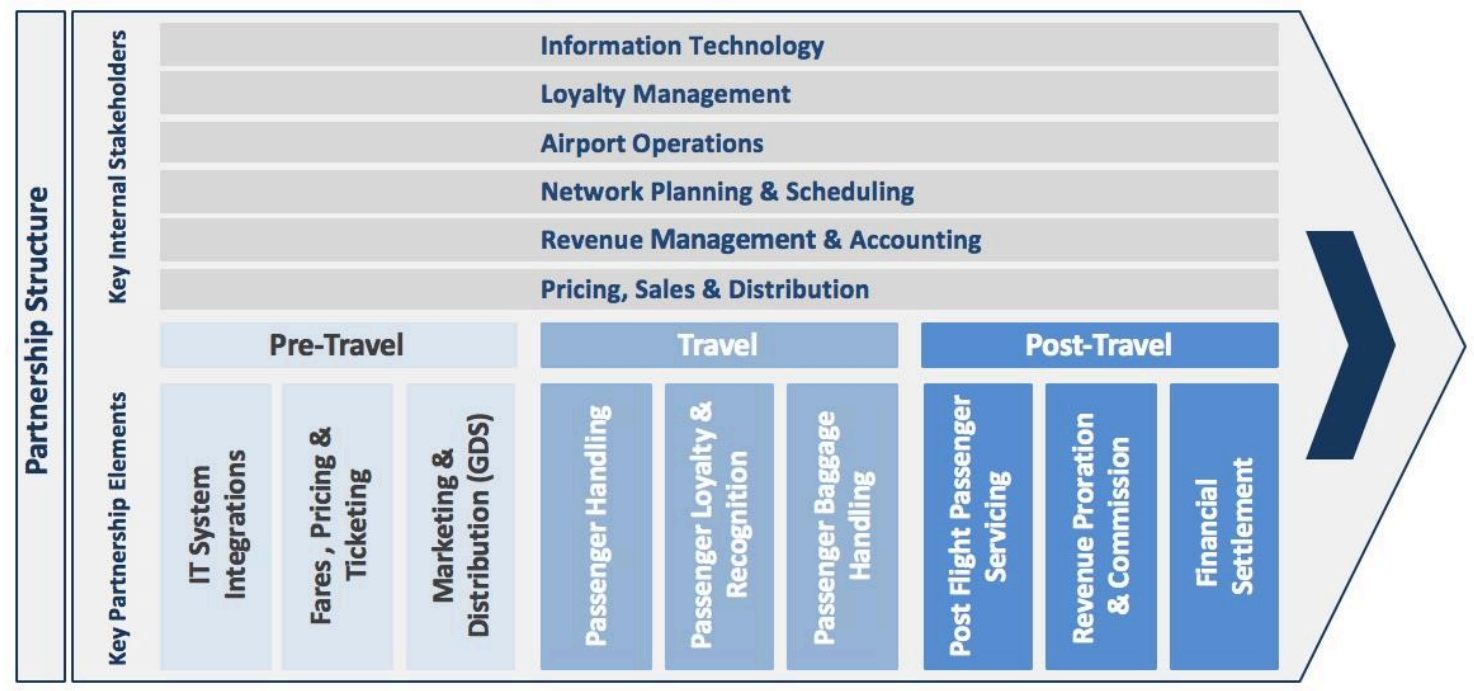

Figure 2. The complexity of the partnership implementation chain.

Source: Own elaboration.

The basic form of airline partnerships are interline cooperation's. This partnership mechanism has been an essential element of international aviation since the 1950s (Fichert, 2013) and allows passengers to purchase a single ticket, in a single transaction, in one currency and a single contract for a journey that requires connecting at an intermediate point between the two cooperating carriers (IATA, 2004). The next iteration of airline cooperation is codesharing which became popular in the US following the air transport market deregulation in 1978 and emerged as standard practice for partnership around the globe (Steer Davies Gleave, 2007). The codeshare mechanism can be seen as extension to the interline mechanism whereby the carrier operating a given flight allows other airlines to market this flight and issue tickets for it as if they were operating the flight themselves (Morandi et al., 2015). Finally, largely build upon the usual interlining 
and codeshare mechanisms, global airline alliances and joint ventures represent advanced strategic alliances in which interline and codeshare components are still present (Competition Commission of Singapore, 2016).

\subsection{Airports challenging the legacy}

One of the key developments that has shaped the airline industry over the last decades is the emergence and inexorable growth of LCCs (de Wit \& Zuidberg, 2012). This industry evolution led to an increasing number of non-connected airline networks as the archetypical LCC business model does not encompass network connectivity, neither interline nor online (Morandi et al., 2015). Since the large coverage of LCC networks provide opportunities to connect (Malighetti, 2008) some passengers started building their own itineraries by combining multiple tickets and taking care of their own baggage transfer (Suau-Sanchez et al., 2017).

The phenomenon of passenger self-connectivity was first defined in the academic literature as 'self-help hubbing' (Burghouwt, 2007) or just 'self-hubbing' (Groß \& Schröder, 2007) and Malighetti (2008) provided first insights about the potential for selfhelp hubbing in the European market. Prior to that, four airports in Germany, namely Cologne-Bonn (2006) and the three airports of Berlin (2007) launched airport led-transfer schemes which were then shortly thereafter addressed from an academic perspective by Grimme (2008). Passengers continued to self-connect, the LCC and Full Service Network Carrier (FSNC) business models converged (Daft \& Albers, 2015; Fageda et al., 2015), and new airport-led transfer schemes in Milan-Malpensa (2011), Singapore (2012) London-Gatwick (2013) and London-Stansted (2018) emerged thanks to the ongoing technological advancements (Cserep, 2016) including the arrival of new online travel providers identifying and facilitating the sale of self-connecting itineraries (Grimme et al., 2016). Some more recent contributions analyse the potential for self-connectivity in different markets (Suau-Sanchez et al., 2016, 2017; Maertens et al., 2016a) and the evolution of airline business models and schemes for assisting self-connecting passengers (Fichert \& Klophaus, 2016).

Airport-led transfer schemes are the airports' response to the potential that nonconnected LCC networks offer which, until their inception, were already being selfconnected by passengers and promoted by travel providers (Figure 3). While airport-led transfer schemes represent a win-win-win situation in which passengers, airlines and airports benefit, the existing schemes differ in their setup and strategy (Figure 4). One key difference among them is whether the airport operates the scheme autonomously without the airlines (e.g. ViaMilano) or if they entail an airport-airline-co-operation to facilitate the passenger self-connection as it is the case for GatwickConnects. In the case of GatwickConnects, the adopting airline is required to provide the airport access to their check-in system while granting the airport's booking website direct access into the airline's reservations system is optional. 


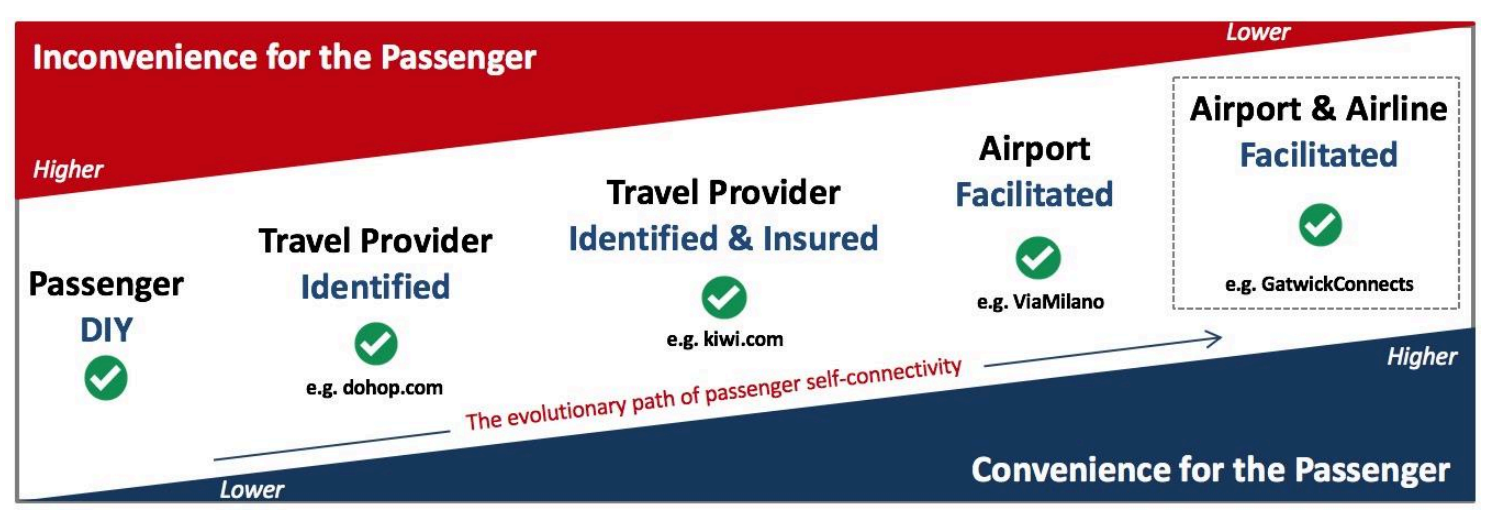

Figure 3. The evolutionary path of passenger self-connectivity. Source: Own elaboration.

\begin{tabular}{|c|c|c|c|c|c|}
\hline & 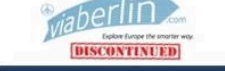 & $\begin{array}{c}\text { (i) Cologne Bonn Connect } \\
\text { Discostisitim }\end{array}$ & ViaMilanoe & $\begin{array}{l}\text { Changi Connects } \\
\text { [NC]11] }\end{array}$ & CONIECTS \\
\hline Launch Year & 2006 & 2007 & 2011 & 2012 & 2013 \\
\hline $\begin{array}{l}\text { Airport-Airline } \\
\text { Co-operation }\end{array}$ & No & Yes & No & Yes & Yes \\
\hline Airlines Included & $\begin{array}{c}\text { All @ the } \\
\text { 3 Berlin airports }\end{array}$ & $\begin{array}{l}2 \text { Germanwings } \\
\text { \& Tuifly }\end{array}$ & All @ MXP & Scoot \& Tigerair & 15 \\
\hline Distribution & Dedicated website & Dedicated website & $\begin{array}{l}\text { Dedicated website } \\
\text { \& GDS (pop-up*) }\end{array}$ & $\begin{array}{l}\text { airline.com } \\
\text { (Scoot \& Tiger) }\end{array}$ & $\begin{array}{l}\text { Dedicated website** } \\
\text { skyscanner.com } \\
\text { dohop.com }\end{array}$ \\
\hline $\begin{array}{l}\text { \# of ticket booking / } \\
\text { financial transactions }\end{array}$ & $2 / 2$ & $1 / 1$ & $2 / 2$ & $1 / 1$ & $1 / 3$ \\
\hline $\begin{array}{l}\text { Passenger Usage } \\
\text { Fee (per connection) }\end{array}$ & None & None & None & approx. $€ 13.80$ & approx. $€ 14.80$ \\
\hline $\begin{array}{l}\text { Passenger / } \\
\text { Baggage connection }\end{array}$ & $\begin{array}{l}\text { Via landside } \\
\text { Via landside }\end{array}$ & $\begin{array}{l}\text { Via landside } \\
\text { Airside bag-drop }\end{array}$ & $\begin{array}{l}\text { Via landside (fast track) } \\
\text { Airside bag-drop }\end{array}$ & $\begin{array}{l}\text { Remain airside } \\
\text { Through-checked }\end{array}$ & $\begin{array}{l}\text { Via landside (fast track) } \\
\text { Airside bag-drop }\end{array}$ \\
\hline Insurance & $\begin{array}{l}\text { Optional } \\
(€ 8.00)\end{array}$ & $\begin{array}{c}\text { Optional } \\
\text { (€7.50) }\end{array}$ & Included & Included & Included \\
\hline Comments & $\begin{array}{l}\text { - Essentially just a } \\
\text { search-engine to } \\
\text { identify flights via } \\
\text { Berlin } \\
\text { - Ceased operations } \\
\text { approx. 2010 (last } \\
\text { mentioned in Annual } \\
\text { Report 2009) } \\
\text { - Shuttle between the } \\
\text { Berlin airports (fee) }\end{array}$ & $\begin{array}{l}\text { - Connections between } \\
\text { Germanwings \& Tuifly } \\
\text { - Operational platform } \\
\text { also used for German- } \\
\text { wings online transfers } \\
\text { ('Smart Connect') } \\
\text { - Ceased operations in } \\
2010 \text { (Tuifly ceased LCC } \\
\text { operations) } \\
\text { - New attempt in } 2018 \\
\end{array}$ & $\begin{array}{l}\text { Booking functionality } \\
\text { added in } 2012 \\
\text { - To qualify a passenger } \\
\text { needs have two tickets } \\
\text { connecting at MXP } \\
\text { (restrictions) } \\
\text { - Passenger can apply } \\
\text { post ticket purchase for } \\
\text { the scheme }\end{array}$ & $\begin{array}{l}\text { Current status unclear } \\
\text { Changi Connects was } \\
\text { the platform for 'Scoot } \\
\text { Through' \& 'Tiger } \\
\text { Connect' } \\
\text { - Recently Singapore } \\
\text { Airlines \& SilkAir, were } \\
\text { added to 'Scoot } \\
\text { Through' \& 'Tiger } \\
\text { Connect' }\end{array}$ & $\begin{array}{l}\text { - Airline participation on } \\
\text { opt-in base } \\
\text { - Booking functionality } \\
\text { including insurance for } \\
\text { misconnection added } \\
\text { in } 2015 \\
\text { (GatwickConnects+) } \\
\text { - Tickets must be } \\
\text { purchased through } \\
\text { dedicated website }\end{array}$ \\
\hline
\end{tabular}

Figure 4. Airport-led transfer schemes at a glance.

Source: Fichert \& Klophaus (2016); Grimme (2008); Grimme (2011); www.berlin-airport.de; www.cologne-bonn-connect.com (archived); www.flyscoot.com; www.flyviamilano.eu; www.gatwickairport.com; www.koeln-bonn-airport.de; www.tigerairways.com; www.viaberlin.com (archived).

\subsubsection{The passengers' perspective}

Theoretically, all passengers are presented with the option to self-connect, but this opportunity is primarily utilised by price sensitive travellers willing to trade time, convenience and airline responsibility, in case of misconnections, for lower airfares (Suau-Sanchez et al. 2016). The availability of airport-led transfer schemes means that a 'Do It Yourself' (DIY) self-connection can be converted into an airport facilitated selfconnection which should have a higher attractiveness for the passenger. The utility for the passenger should increase primarily due to: a) providing access to an internet-based booking platform to identify and purchase connect-itineraries on non-connected airline networks (Fichert \& Klophaus, 2016) with one booking transaction (GatwickConnects, 2016); b) offering a transfer experience that reduces inconvenience by giving access to 
check-in and bag-drop facilities located airside close to the baggage claim area (Fichert \& Klophaus, 2016; GatwickConnects, 2016); c) providing assistance and/or compensations in case of schedule changes prior to departure or in case of misconnections during the journey (Fichert \& Klophaus, 2016; GatwickConnects, 2016); d) allowing usage of the fast-track security lane to re-enter airside (GatwickConnects, 2016); e) offering additional soft-benefits such as discount vouchers for duty free shopping, meals or lounge access (Fichert \& Klophaus, 2016; GatwickConnects, 2016).

Although airport-led transfer scheme connections should have a higher utility for the passenger versus DIY self-connecting, certain characteristics and limitations potentially constrain the utility. The utility for the passenger might not be fully realised primarily due to: a) the need to be aware of the concept and the distribution channels that identify and sell airport facilitated self-connection itineraries (Maertens et al., 2016a; Suau-Sanchez et al., 2016); b) non-competitive ticket fares as the sum-of-sectors fare plus the airport connection fee might not be competitive vis-à-vis traditional ticket fares for instance due to double-marginalisation or double-charging of fees and taxes (Fichert \& Klophaus, 2016); c) the need to clear through customs and immigrations (depending on the actual passenger journey) which not only creates inconvenience but also requires valid travel documents (Fichert \& Klophaus, 2016); d) the fact that the airport provided transfer services are not able to mimic all service functions that an airline offers, for instance visa checks or booking amendments (GatwickConnects, 2015); e) some services are only available during normal business hours (06:00 to 18:00 in case of the manned GatwickConnects desks) (GatwickConnects, 2016).

Of the constraining factors presented above, the potential non-competitiveness of ticket fares is a salient issue because, although limited knowledge about the characteristics of self-connecting passengers exists (Suau-Sanchez et al., 2016), it is rather obvious that the majority of passengers would consider self-connecting only if it means lower ticket fares. In this regard, a study by OAG (2016) suggests that $40 \%$ of all passengers would consider self-connecting if they saved at least $\$ 100$. Another critical constraining factor is the mentioned lack of passenger awareness of airport-led transfer schemes. The limited marketability of itineraries involving an airport facilitated selfconnection is another constraining factor since tickets cannot be purchased via traditional sales channels such as the airlines' websites or through an online or offline travel agent using a GDS (Suau-Sanchez et al., 2016; Cserep, 2016). ${ }^{1}$

\subsubsection{The airports' perspective}

Any revenue benefits for airports offering airport-led transfer schemes primarily arises from attracting incremental transfer passengers which in turn should increase aviation and non-aviation revenues (Malighetti et al., 2008). The aforementioned is valid for both traditional airports hosting an airline hub an airports home of a low-cost base. Indeed, Suau-Sanchez et al. (2016) highlight that the largest levels of potential self-connectivity are for airports with the highest levels of traditional connectivity such as Heathrow or Frankfurt. Other airports were more potential self-connectivity is observed are airports with large low-cost bases, like Barcelona, Gatwick or Manchester. Fageda et al. (2015) argue that these airports should consider facilitating passenger self-connections to

\footnotetext{
${ }^{1}$ In the case of GatwickConnects at least two meta-search engines (skyscanner.com \& dohop.com) have the ability to identify itineraries involving non-connected airline networks via LGW and inform the passenger at the time of booking about the existence of the scheme. In case of booking, the passenger gets transferred to the airport's booking website where then two tickets including the GatwickConnects+ service can be purchased in one booking transaction but three financial transactions (GatwickConnects, 2016).
} 
increase the airports' competitive position, for instance when it comes to route development or attracting new airlines.

What must not be forgotten is that the theoretical expected benefits do not come for free as the airport must plan, implement, promote and operate the respective transfer products and services. The associated costs must be covered through incremental revenues, by charging a passenger usage fee or by a combination of the two (Maertens et al., 2016a).

\subsubsection{The airlines' perspective}

Airlines are waking up to the potential of self-connectivity and airport-led transfer schemes (Harrison, 2015; Gunnarsson, 2016). In this regard the literature concludes that the overarching motivation for airlines to adopt such schemes is attracting additional transfer passengers (Maertens et al., 2016a), which then creates financial benefits for the airlines linked to economies of density (Fageda et al., 2015). Maertens et al. (2016a) further argue that airport-led transfer schemes can generate those transfer passengers with very limited or without any additional production costs.

Additional transfer passengers might either come from the airlines own network, if online connectivity is not offered already, or from other airlines participating in the scheme. Due to the latter, airport-led transfer schemes have the potential to generate benefits usually associated with partnerships realized through legacy mechanisms. These benefits include access to additional feed, an extended network reach, a better marketability of the non-connected airline networks and a more seamless transfer experience for the passenger. Therefore, airport-led transfer schemes can be considered as an innovative partnership mechanism that challenges, to some extent, the legacy of interline and codesharing.

Nevertheless, there are some caveats and airlines might show resistance to participate in such an airport-led transfer schemes. While LCCs could consider participating in such schemes as a deviation from their original business model, FSNCs might not see a substantial benefit in carrying a few more passengers or even fear cannibalizing their own network. Issues related to brand and service homogeneity could also prevent FSNCs from participating in such schemes.

Hence, our literature review indicates that the topic of airport-led transfer schemes is not yet widely addressed, with only a limited amount of publications that primarily focus on the potential of self-connectivity and its implications for the airports. The role of the airlines is only superficially addressed and little understanding seems to exist about why airlines could, or could not be interested in adopting airport-led transfer schemes. This paper aims at contributing to the closure of the gap by implementing empirical research that focuses on unveiling, ranking and assessing perceived drivers and barriers for the airline adoption of airport-led transfer schemes as a mechanism to establish interairline network connectivity.

\section{METHODOLOGY}

\subsection{Methods}

We use a mixed-method research approach utilising academic and non-academic literature, qualitative interviews as well as a quantitative questionnaire. As the quantitative questionnaire constituted the most significant data collection instrument, the chosen research approach could also be described as a survey within a case study strategy (Yin, 2014). A single case study design has been selected focusing on GatwickConnects, as this scheme was considered the most successful airport-led transfer scheme to date. 
Firstly, we identify the drivers and barriers from the relevant literature employing a systematic review. This review results in an extensive list of potential drivers and barriers that are explicitly and implicitly mentioned in the relevant literature. Given the limited amount of relevant literature, selected stakeholders were interviewed with the aim to unveil additional drivers and barriers. Interview participants were chosen through purposive sampling by the authors aiming for a heterogeneous group of stakeholders directly and indirectly involved in or exposed to airport-led transfer schemes. The motivation for selecting participants across the different stakeholder groups, and not just within the airlines, was based on the objective to capture potential drivers and barriers for airline adoption as perceived by different key stakeholders. In total, nine interview respondents were identified, who came from different sectors in the aviation industry and had been involved in airport-led transfer schemes (Table 2). Interviews were conducted in February 2017, five of which were telephone interviews and four were face-to-face. Anonymity was granted to safeguard personal privacy at the beginning of the interviews, which lasted between thirty minutes and one hour.

Table 2. List of interview participants.

\begin{tabular}{|l|l|l|}
\hline$\#$ & Sector & Job title \\
\hline 1 & Airline Consultancy & Head of Aviation Practice \\
\hline 2 & Airline Consultancy & Partner \\
\hline 3 & Airline Consultancy & Principal \\
\hline 4 & Airline Technology Provider & General Manager \\
\hline 5 & Airport Operator & Business Development Manager \\
\hline 6 & Global Airline Alliance & Director Membership Development \\
\hline 7 & Global Airline Alliance & Director Strategy \\
\hline 8 & Online Travel Provider & Chief Executive Officer \\
\hline 9 & Passenger Airline & Airport Station Manager \\
\hline
\end{tabular}

Secondly, once the drivers and barriers are identified, a survey is used to collect quantitative data about how airline industry professionals with experience in airline partnerships perceive those previously identified drivers and barriers. A self-administered online questionnaire using the Qualtrics Survey Platform was developed largely based on the data and intelligence gained during the qualitative research phase. The GatwickConnects scheme was used as blue-print to outline the airport-led transfer scheme concept in the introductory section without disclosing the actual airport operator to the participants.

The majority of the questions in the questionnaire were closed-ended rating questions aimed at capturing opinion variables through a five-point Likert scale. The labelling of the rating scale followed Saunders et al. (2009) recommendations. The most relevant questions, those regarding the potential drivers and barriers, were mostly presented to the survey participants in three matrices, one for potential drivers and two for potential barriers. The decision to employ matrices was made as they warranted a convenient and comprehensible presentation of the various drivers and barriers in the questionnaire. The decision for utilising matrices, however, was only made after critically reviewing comments from Dillman et al. (2014) that caution the usage of matrices but also provide best practices to simplify and optimise matrix questions. These guidelines were utilised as we ultimately considered matrices to be the most appropriate format for the questions asked.

In addition to any closed-ended questions, several open-ended questions were added to enable the respondents to contribute additional drivers and barriers or to leave 
comments for specific topics of interest. All open-ended questions were optional to answer while all other questions were mandatory to complete.

Questions were formulated ensuring clear wording and, as suggested by Krosnick \& Presser (2010), the 'Question Understanding Aid' tool (QUAID) was utilised to identify and if possible alter problematic questions with respect to unfamiliar technical terms, vague or imprecise relative terms, vague or ambiguous noun-phrases, complex syntax and working memory overload. As using some airline partnership terms could not be avoided, several jargon words were further explained to the respondents if they hovered their mouse-cursor over various underlined words in the questionnaire. The final flow of the questionnaire including question blocks and the respective amount of questions is presented in Figure 5.

The selection of survey participants aimed at a more homogeneous group where all respondents had to have professional experience in airline partnerships. In total, 71 potential participants were invited via electronic correspondence. Participants were also asked to nominate other potential respondents that could contribute and thus the sampling included a snowball component. The survey was open from 13 March 2017 to 7 April 2017. A total of 47 questionnaires were completed (response rate of 66\%). The respondents were from airlines, mainly from FSNCs, but also from Charter, LCCs, and Regionals $^{2}$, aviation consultancy firms, airline alliances, airports and other aviation industry sectors (Figures 6 and 7).

The data gathered through the survey research was analysed utilising univariate descriptive statistics focusing on the mean and the standard deviation to identify the significance of each drivers and barrier (mean), rank them by significance relative to one another (mean ranking) and to measure the agreement amongst the survey participants (standard deviation). For this research, any drivers and barriers with a mean score (MS) of $\geq 3.8$ was considered a key driver or barrier.

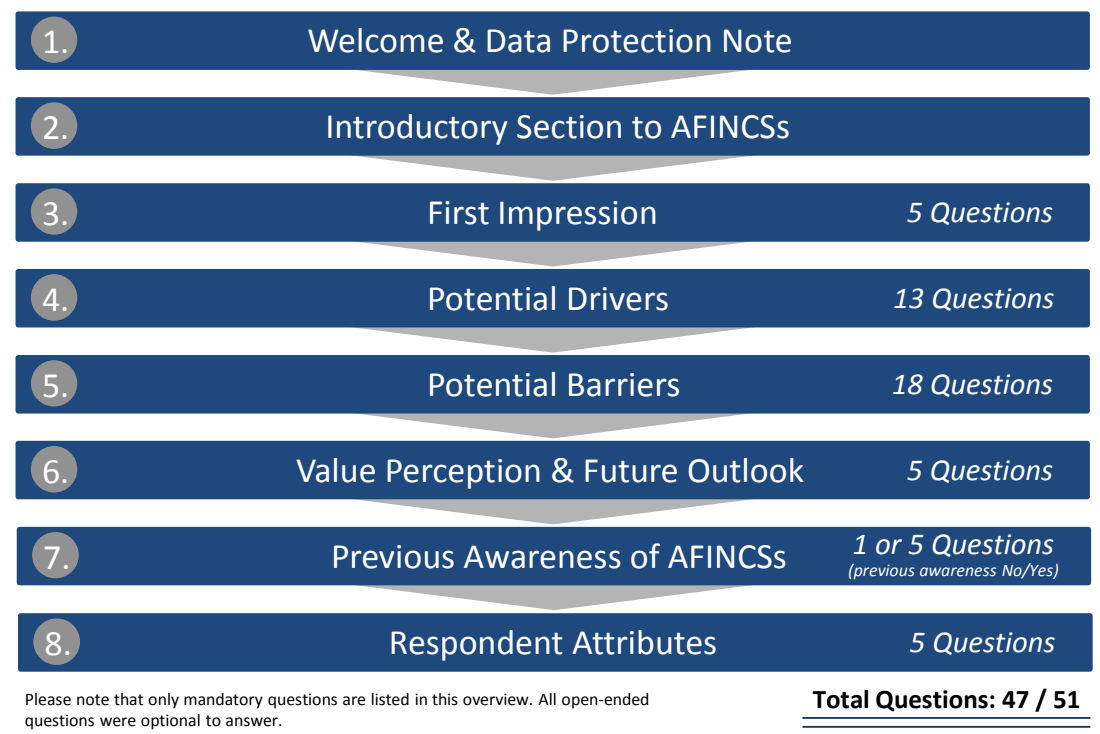

Figure 5. Survey structure.

Source: Own elaboration.

\footnotetext{
${ }^{2}$ While the overrepresentation of FSNCs respondents does not have a negative effect on the survey results, it must be kept in mind when analysing and interpreting the results.
} 


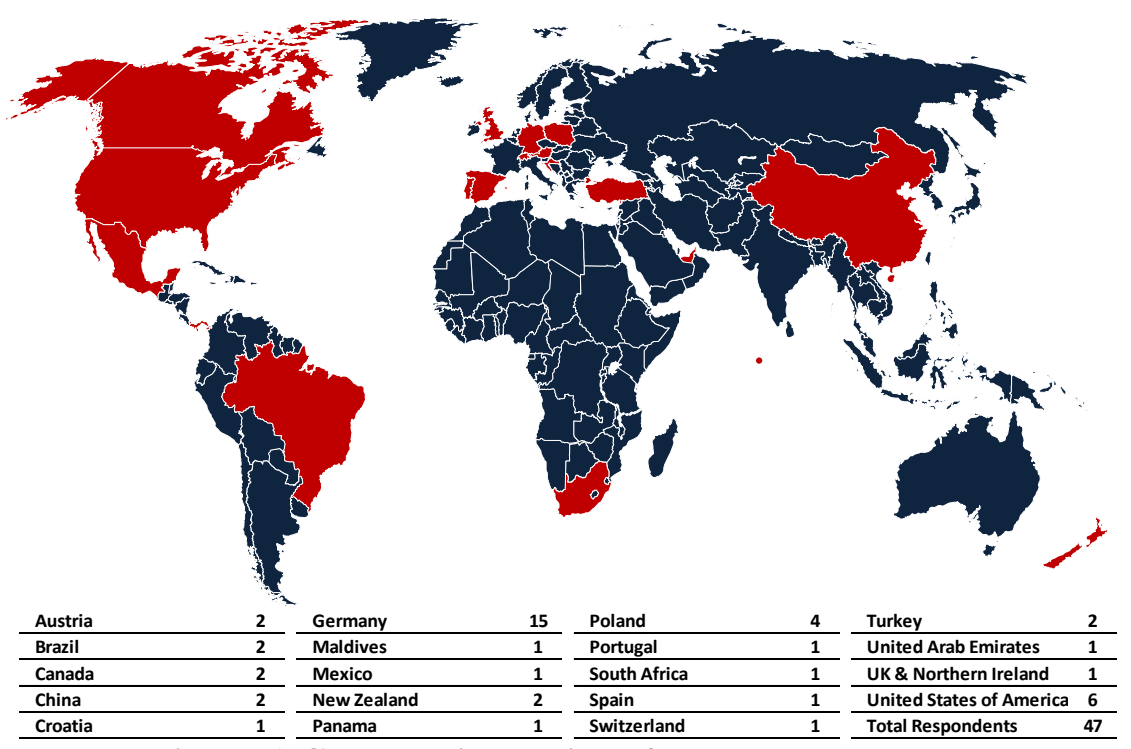

Figure 6. Geographic location of survey respondents.

Source: Own elaboration.

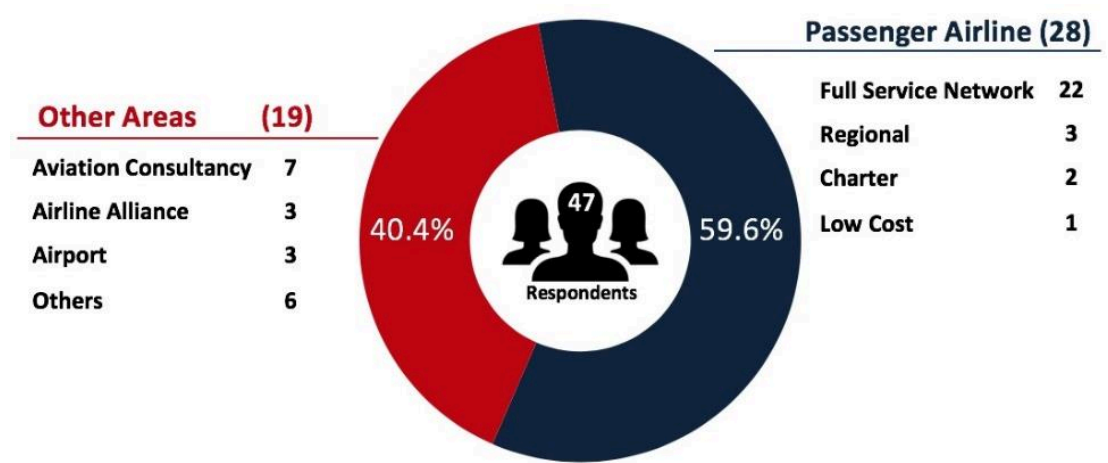

Figure 7. Employment by sector of survey respondents.

Source: Own elaboration.

\subsection{Analytical framework: Innovation diffusion theory}

Innovations have attracted the interest of scholars who have researched innovative products, services or ideas from a diverse set of academic perspectives and across different disciplines (Cheng et al., 2004). An innovation can be defined as "an idea, practice, or object that is perceived as new by an individual or other unit of adoption" (Rogers, 2003 p. 12). Based on this simple but concise definition, and with the intelligence gained from the literature review, we could consider airport-led transfer schemes as an innovative concept emerging in the airline industry. Consequently, the innovation diffusion theory (IDT) was utilised to support the process of unveiling, ranking and assessing potential drivers and barriers for the airline adoption of AFINCSs.

The innovation diffusion theory has several contributors (Bass, 1969; Moore \& Harley, 2008), but Rogers $(1964,2003)$ is considered as the founding father of IDT. According to Rogers (2003, p. 11), "diffusion is the process by which an innovation is communicated through certain channels over time among the members of a social system". IDT has been extensively applied in academic research (Frambach \& Schillewaert, 2002) and has also been used in air transport related research, for instance by Breitenmoser et al. (2013), Galang (2012), Liang \& James (2009) or Segerstedt \& 
Grote (2016). Over the decades, two major research streams emerged, one being the process of innovation diffusion and the other one being the characteristics of innovations and their impact on adoption (Kim \& Ammeter, 2014). The characteristics, or to be more precise, the perceived characteristics of innovations, are of prime interest as they have the ability to either drive or impede the adoption process (Kapoor et al., 2014). Hence, in line with our research aim, the focus was put on perceived innovation characteristics and how they could act as drivers or barriers for airline adoption.

According to Rogers (2003, p.168), "the innovation-decision process (IDP) is a process through which an individual (or other decision-making unit) passes from gaining initial knowledge of an innovation, to forming an attitude toward the innovation, to making a decision to adopt or reject, to implementation of the new idea, and to confirmation of the decision". Based on Rogers' IDP, an airline that is considering adopting an airport-led transport scheme would go through a process of up to five stages: knowledge, persuasion, decision, implementation, confirmation.

Frambach and Schillewaert (2002) developed a multi-level framework of organisational innovation adoption through identifying and integrating factors that have been previously recognised to promote or impede organisational innovation adoption. Furthermore, they also incorporate to their framework elements of classical models of organisational buying behaviour. The first level of their framework, that of organisational innovation adoption, is of prime value for our analysis.

Two main similarities with the previously presented IDP of Rogers can be recognised. Firstly, Frambach and Schillewaert's framework also presents five sequential stages which to the largest extent are comparable with the stages in Rogers' IDP. Secondly, five of the six perceived innovation characteristics are identical to the ones mentioned in Rogers' IDP while only "Uncertainty" was added by the authors (Figure 8).

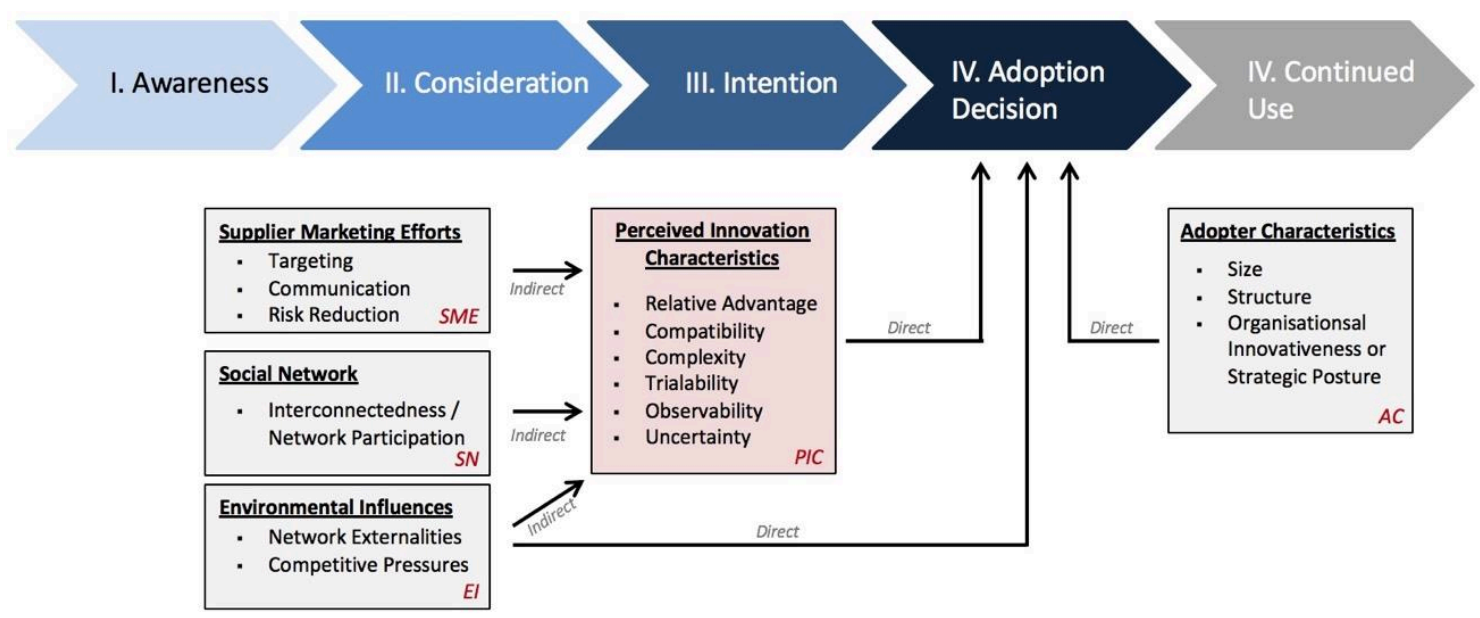

Figure 8. Framework of organisational innovation adoption.

Source: Authors adapted from Frambach and Schillewaert (2002)

In contrast to Rogers' IDP, Frambach and Schillewaert's framework not only incorporates the effects that directly influence the adoption decision, for instance the perceived innovation characteristics, but also indirect effects, for instance the supplier marketing efforts. In total, Frambach and Schillewaert (2002) suggest five sets of determinants that influence the innovation adoption decision: the Adopter Characteristics (AC), the Environmental Influences (EI), the Perceived Innovation Characteristics (PIC), the Social Network (SN), and the Supplier Marketing Efforts (SME). 


\section{RESULTS}

\subsection{Drivers and Barriers}

Based on the literature review and interviews, a total of 17 drivers and 21 barriers with the potential to impact the airline adoption of AFINCSs were identified. These are summarised in Tables 3, 4, 5 and 6.

\begin{tabular}{|c|c|c|c|c|c|}
\hline TEbhest Ident & iflodvdrivers (I). & $\begin{array}{l}\text { Literature / } \\
\text { Interview }\end{array}$ & Description & F\&S & ID \\
\hline $\begin{array}{l}\text { Partnership } \\
\text { Structure }\end{array}$ & $\begin{array}{l}\text { Limited } \\
\text { Additional } \\
\text { Costs }\end{array}$ & $\begin{array}{l}\text { Lit: Maertens et al. } \\
\text { (2016a) } \\
\text { Int: Yes }\end{array}$ & \multirow{2}{*}{$\begin{array}{l}\text { AFINCSs require little investment and } \\
\text { limited lifecycle effort from the airline. } \\
\text { Involvement is usually limited to provide the } \\
\text { airport with access to the airline check-in } \\
\text { system, as well as establishing a connection } \\
\text { between the airport's booking platform and } \\
\text { the airline's reservation system (optional). }\end{array}$} & PIC & D_01 \\
\hline $\begin{array}{l}\text { Partnership } \\
\text { Structure }\end{array}$ & $\begin{array}{l}\text { Limited } \\
\text { Additional } \\
\text { Complexity } \\
\end{array}$ & $\begin{array}{l}\text { Lit: N/A } \\
\text { Int: Yes }\end{array}$ & & $\mathrm{PIC}$ & D_02 \\
\hline $\begin{array}{l}\text { Partnership } \\
\text { Structure }\end{array}$ & $\begin{array}{l}\text { Low Risk } \\
\text { Trialability: } \\
\text { Costs }\end{array}$ & $\begin{array}{l}\text { Lit: N/A } \\
\text { Int: Yes }\end{array}$ & $\begin{array}{l}\text { As implementing an AFINCS requires little } \\
\text { up-front investment, the scheme can be } \\
\text { trialled by airlines with low financial risks. }\end{array}$ & PIC & D_03 \\
\hline $\begin{array}{l}\text { Partnership } \\
\text { Structure }\end{array}$ & $\begin{array}{l}\text { Low Risk } \\
\text { Trialability: } \\
\text { Operations }\end{array}$ & $\begin{array}{l}\text { Lit: Fichert \& } \\
\text { Klopphaus (2016) } \\
\text { Int: Yes }\end{array}$ & $\begin{array}{l}\text { As implementing an AFINCS require almost } \\
\text { no change to the airlines' operations, the } \\
\text { concept can be trialled with low operational } \\
\text { risks. }\end{array}$ & PIC & D_04 \\
\hline $\begin{array}{l}\text { Partnership } \\
\text { Structure }\end{array}$ & $\begin{array}{l}\text { No Change } \\
\text { in Business } \\
\text { Model } \\
(\mathrm{P} 2 \mathrm{P})\end{array}$ & $\begin{array}{l}\text { Lit: Fichert \& } \\
\text { Klopphaus (2016) } \\
\text { Int: Yes }\end{array}$ & $\begin{array}{l}\text { AFINCSs do not require the airline to alter its } \\
\text { underlying business model }\end{array}$ & $\mathrm{AC}$ & D_05 \\
\hline $\begin{array}{l}\text { Partnership } \\
\text { Structure }\end{array}$ & $\begin{array}{l}\text { Connectivity } \\
\text { Across } \\
\text { Business } \\
\text { Models }\end{array}$ & $\begin{array}{l}\text { Lit: } \\
\text { GatwickConnects } \\
(2015) \\
\text { Int: Yes }\end{array}$ & $\begin{array}{l}\text { AFINCSs connect the networks of all carriers } \\
\text { irrespective of their business model. }\end{array}$ & PIC & D_06 \\
\hline $\begin{array}{l}\text { Partnership } \\
\text { Structure }\end{array}$ & $\begin{array}{l}\text { No Inter-Airline } \\
\text { Partnership } \\
\text { Agreement } \\
\text { Required }\end{array}$ & $\begin{array}{l}\text { Lit: Capobianco } \\
(2016) \\
\text { Int: No }\end{array}$ & $\begin{array}{l}\text { In an AFINCS the participating airline only } \\
\text { enters into one agreement with the airport. }\end{array}$ & PIC & D_07 \\
\hline $\begin{array}{l}\text { IT Systems } \\
\text { Integration }\end{array}$ & $\begin{array}{l}\text { No Inter-Airline } \\
\text { IT System } \\
\text { Integration } \\
\text { Required }\end{array}$ & $\begin{array}{l}\text { Lit: N/A } \\
\text { Int: Yes }\end{array}$ & $\begin{array}{l}\text { In AFINCSs, the passengers will book } \\
\text { directly with the respective airlines via the } \\
\text { airports' website, through an OTA or directly } \\
\text { with the carrier. }\end{array}$ & PIC & D_08 \\
\hline $\begin{array}{l}\text { Passenger } \\
\& \\
\text { Baggage } \\
\text { Handling }\end{array}$ & $\begin{array}{l}\text { No Inter-Airline } \\
\text { Transfer Process } \\
\text { Required }\end{array}$ & $\begin{array}{l}\text { Lit: Morandi et al. } \\
(2015) \text {; Stamp } \\
(2016) \\
\text { Int: Yes }\end{array}$ & $\begin{array}{l}\text { In an AFINCS, the transfer process is } \\
\text { essentially taken over by the passenger, but } \\
\text { facilitated by the airport. Costs arising from } \\
\text { the facilitation are not charged to the airlines } \\
\text { but are covered by a connection fee the } \\
\text { passenger pays. }\end{array}$ & PIC & D_09 \\
\hline $\begin{array}{l}\text { Passenger } \\
\& \\
\text { Baggage } \\
\text { Handling }\end{array}$ & $\begin{array}{l}\text { Eliminate } \\
\text { the Inter-Airline } \\
\text { Misconnection } \\
\text { Risk }\end{array}$ & $\begin{array}{l}\text { Lit: Cserep (2016); } \\
\text { Fichert \& } \\
\text { Klopphaus (2016); } \\
\text { Harrison (2015) } \\
\text { Int: Yes }\end{array}$ & $\begin{array}{l}\text { In an AFINCS itinerary the passenger has } \\
\text { two separate tickets and in case of } \\
\text { misconnection the airport will take care of the } \\
\text { passenger handling, rebooking and absorb the } \\
\text { additional costs arising. }\end{array}$ & PIC & D_10 \\
\hline
\end{tabular}

Note: Lit $=$ Literature Review; Int $=$ Interview; N/A $=$ Not Available; F\&S $=$ Frambach and Schillewaert's determinants. 
Table 4. Identified drivers (II).

\begin{tabular}{|c|c|c|c|c|c|}
\hline Element & Driver & $\begin{array}{l}\text { Literature / } \\
\text { Interview }\end{array}$ & Description & F\&S & ID \\
\hline $\begin{array}{l}\text { Post Flight } \\
\text { Passenger } \\
\text { Servicing }\end{array}$ & $\begin{array}{l}\text { Reduced } \\
\text { Passenger } \\
\text { Compensation } \\
\text { Liability } \\
\text { (if applicable) }\end{array}$ & $\begin{array}{l}\text { Lit: N/A } \\
\text { Int: Yes }\end{array}$ & $\begin{array}{l}\text { As AFINCS itineraries are booked in one } \\
\text { transaction but with two separate tickets, the } \\
\text { compensation liability for the airlines } \\
\text { involved is limited to the respective flight } \\
\text { they operate. }\end{array}$ & PIC & D_11 \\
\hline $\begin{array}{l}\text { Revenue } \\
\text { Proration } \\
\& \\
\text { Commission }\end{array}$ & $\begin{array}{l}\text { No } \\
\text { Prorate } \\
\text { Dilution }\end{array}$ & $\begin{array}{l}\text { Lit: Grimme } \\
(2008) ; \text { Holloway } \\
\text { (2008) } \\
\text { Int: Yes }\end{array}$ & $\begin{array}{l}\text { In absence of through-fares, passengers } \\
\text { buying tickets for an AFINCS itinerary, } \\
\text { essentially pay a sum-of-sector fare. } \\
\text { Consequently, prorate dilution, which occurs } \\
\text { when airlines could have earned more from } \\
\text { taking two local passengers instead of one } \\
\text { connect passenger cannot occur. }\end{array}$ & PIC & D_12 \\
\hline $\begin{array}{l}\text { Financial } \\
\text { Settlement }\end{array}$ & $\begin{array}{l}\text { No Interline } \\
\text { Billing Audits }\end{array}$ & $\begin{array}{l}\text { L: N/A } \\
\text { Int: Yes }\end{array}$ & $\begin{array}{l}\text { Passengers buying an AFINCS itinerary are } \\
\text { purchasing separate tickets with each airline and } \\
\text { thus the airlines are not required to settle \& audit } \\
\text { any revenues with their partners. }\end{array}$ & $\mathrm{PIC}$ & D_13 \\
\hline $\begin{array}{l}\text { Financial } \\
\text { Settlement }\end{array}$ & $\begin{array}{l}\text { No } \\
\text { Impact on Accounts } \\
\text { Receivable } \\
\text { Turnover }\end{array}$ & $\begin{array}{l}\text { Lit: Holloway (2008) } \\
\text { Int: Yes }\end{array}$ & $\begin{array}{l}\text { In an AFINCS each airline will receive its revenue } \\
\text { portion at time of booking (if booked directly with } \\
\text { the airline) or shortly after the booking from the } \\
\text { OTA or provider of the airport's booking platform. }\end{array}$ & $\mathrm{PIC}$ & D_14 \\
\hline Miscellaneous & $\begin{array}{l}\text { Participation Instead } \\
\text { of Observation }\end{array}$ & $\begin{array}{l}\text { Lit: Grimme et al. } \\
(2016) \\
\text { Int: Yes }\end{array}$ & $\begin{array}{l}\text { The recent past has shown that several 3rd parties } \\
\text { (e.g. meta-search engines or OTAs) begin to see a } \\
\text { business opportunity in non-connected airline } \\
\text { networks. These ventures do not require } \\
\text { participation from the airlines which also means } \\
\text { airlines have no control over its development and } \\
\text { growth. In AFINCSs airlines at least can } \\
\text { participate and somewhat shape their development. }\end{array}$ & EI & D_15 \\
\hline Miscellaneous & $\begin{array}{l}\text { Connectivity } \\
\text { Bandwagon } \\
\text { Effect }\end{array}$ & $\begin{array}{l}\text { Lit: N/A } \\
\text { Int: Yes }\end{array}$ & $\begin{array}{l}\text { As the business model of LCCs continue to } \\
\text { converge, the once strict P2P and no partnerships } \\
\text { paradigm is further diminishing. As a result, LCCs } \\
\text { but also FSNCs and Hybrids will look into } \\
\text { opportunities to enhance their network connectivity } \\
\text { to remain competitive. }\end{array}$ & EI & D_16 \\
\hline Miscellaneous & $\begin{array}{l}\text { Airline Industry } \\
\text { Inter-connectedness }\end{array}$ & $\begin{array}{l}\text { Lit: N/A } \\
\text { Int: Yes }\end{array}$ & $\begin{array}{l}\text { As the concepts of self-connectivity, airport-led } \\
\text { transfer schemes and AFINCSs are increasingly } \\
\text { addressed at industry expert gatherings, airlines } \\
\text { will become increasingly aware of such schemes. }\end{array}$ & SN & D_17 \\
\hline
\end{tabular}

Note: Lit $=$ Literature Review; Int $=$ Interview; N/A $=$ Not Available; F\&S $=$ Frambach and Schillewaert's determinants. 
Table 5. Identified barriers (I)

\begin{tabular}{|c|c|c|c|c|c|}
\hline Element & Barrier & $\begin{array}{l}\text { Literature / } \\
\text { Interview }\end{array}$ & Description & $\mathbf{F \& S}$ & ID \\
\hline $\begin{array}{l}\text { Partnership } \\
\text { Structure }\end{array}$ & $\begin{array}{l}\text { Incremental } \\
\text { Revenue } \\
\text { Uncertainty }\end{array}$ & $\begin{array}{l}\text { Lit: N/A } \\
\text { Int: Yes }\end{array}$ & $\begin{array}{l}\text { As AFINCSs are fairly new concepts, the potential benefits } \\
\text { an airline can gain from participation, primarily incremental } \\
\text { passengers and revenues, are mostly theoretical with little } \\
\text { empirical evidence. }\end{array}$ & PIC & B_01 \\
\hline $\begin{array}{l}\text { Partnership } \\
\text { Structure }\end{array}$ & $\begin{array}{l}\text { "All or } \\
\text { None" } \\
\text { Partnership }\end{array}$ & $\begin{array}{l}\text { Lit: N/A } \\
\text { Int: Yes }\end{array}$ & $\begin{array}{l}\text { Airlines that join an AFINCS will automatically connect } \\
\text { their network with all airlines participating at that airport. } \\
\text { While one airline might complement the own network, } \\
\text { another one could compete for the same traffic and thus co- } \\
\text { operation has limited value or could be actual detrimental. }\end{array}$ & PIC & B_02 \\
\hline $\begin{array}{l}\text { Partnership } \\
\text { Structure }\end{array}$ & $\begin{array}{l}\text { Risk of } \\
\text { Self-Diversion }\end{array}$ & $\begin{array}{l}\text { Lit: Malighetti } \\
\text { (2016); Suau- } \\
\text { Sanchez et al. } \\
\text { (2016) } \\
\text { Int: Yes }\end{array}$ & $\begin{array}{l}\text { Self-diversion is the risk to divert passengers from the own } \\
\text { direct or online service to itineraries involving a partner } \\
\text { airline. A risk that is generally present in airline partnerships } \\
\text { but much harder to manage in AFINCSs as traditional } \\
\text { mechanisms, e.g. SPAs or Revenue Management, cannot be } \\
\text { utilised. }\end{array}$ & PIC & B_03 \\
\hline $\begin{array}{l}\text { Fares } \\
\& \\
\text { Pricing }\end{array}$ & $\begin{array}{l}\text { Non- } \\
\text { Competitive } \\
\text { Fares: } \\
\text { Double } \\
\text { Marginalisation }\end{array}$ & $\begin{array}{l}\text { Lit: CAPA (2016); } \\
\text { Malighetti (2016) } \\
\text { Int: Yes }\end{array}$ & $\begin{array}{l}\text { Double marginalisation: Combining two separate tickets that } \\
\text { are individually priced means the passenger will have to pay } \\
\text { a sum-of-sectors fare. Consequently, double marginalisation } \\
\text { occurs as both airlines price each segment not considering } \\
\text { the overall price of the trip. This can lead to non- } \\
\text { competitive fares on an O\&D. }\end{array}$ & PIC & B_04 \\
\hline $\begin{array}{l}\text { Fares } \\
\& \\
\text { Pricing }\end{array}$ & $\begin{array}{l}\text { Non- } \\
\text { Competitive } \\
\text { Fares: } \\
\text { Double- } \\
\text { Charging of Fees } \\
\text { \& Taxes }\end{array}$ & $\begin{array}{l}\text { Lit: Cserep (2016); } \\
\text { Fichert \& } \\
\text { Klopphaus (2016) } \\
\text { Int: No }\end{array}$ & $\begin{array}{l}\text { Double charging of fees \& taxes: Although essentially being } \\
\text { a transfer passenger, any fees \& taxes will be based on the } \\
\text { two individual tickets. In many cases this will result in } \\
\text { higher costs as certain fees \& taxes are not applicable or } \\
\text { lower for transfer passengers. }\end{array}$ & PIC & B_05 \\
\hline $\begin{array}{l}\text { Marketing } \\
\& \\
\text { Distribution }\end{array}$ & $\begin{array}{l}\text { Lack of } \\
\text { Passenger } \\
\text { Awareness: } \\
\text { AFINCS O\&D }\end{array}$ & $\begin{array}{l}\text { Lit: Airneth (2015); } \\
\text { Gunnarsson (2016); } \\
\text { Maertens et al. } \\
\text { (2016a) } \\
\text { Int: Yes }\end{array}$ & $\begin{array}{l}\text { Passengers need to be aware that it is possible to travel on } \\
\text { the demanded O\&D using two airlines that do not connect } \\
\text { their networks through traditional partnership agreements. } \\
\text { As of May 2017, only two meta-search engines } \\
\text { (skyscanner.com \& dohop.com) are able to identify such } \\
\text { itineraries and at the same time inform the passenger that } \\
\text { both airlines are connected through an AFINCS. }\end{array}$ & PIC & B_06 \\
\hline $\begin{array}{l}\text { Marketing } \\
\& \\
\text { Distribution }\end{array}$ & $\begin{array}{l}\text { Lack of } \\
\text { Passenger } \\
\text { Awareness: } \\
\text { AFINCS Product }\end{array}$ & $\begin{array}{l}\text { Lit: Cserep (2016); } \\
\text { Grimme (2011); } \\
\text { Suau-Sanchez et al. } \\
\text { (2016) } \\
\text { Int: Yes }\end{array}$ & $\begin{array}{l}\text { Passengers need to be aware that two airlines partner via the } \\
\text { connect-airport and what implications this has. }\end{array}$ & PIC & B_07 \\
\hline $\begin{array}{l}\text { Marketing } \\
\& \\
\text { Distribution }\end{array}$ & $\begin{array}{l}\text { Limited } \\
\text { Distribution } \\
\text { Channels: GDS }\end{array}$ & $\begin{array}{l}\text { Lit: N/A } \\
\text { Int: Yes }\end{array}$ & $\begin{array}{l}\text { GDS inclusion: AFINCS itineraries will not be identified in } \\
\text { the GDS and thus cannot be booked through this sales } \\
\text { channel. }\end{array}$ & PIC & B_08 \\
\hline $\begin{array}{l}\text { Marketing } \\
\& \\
\text { Distribution }\end{array}$ & $\begin{array}{l}\text { Limited } \\
\text { Distribution } \\
\text { Channels: } \\
\text { Airline.com } \\
\end{array}$ & $\begin{array}{l}\text { Lit: Cserep (2016) } \\
\text { Int: Yes }\end{array}$ & $\begin{array}{l}\text { Airline.com inclusion: AFINCS itineraries will not be } \\
\text { identified on either of the two partnering airlines' websites } \\
\text { and thus cannot be booked through this sales channel. }\end{array}$ & PIC & B_09 \\
\hline $\begin{array}{l}\text { Marketing } \\
\& \\
\text { Distribution }\end{array}$ & $\begin{array}{l}\text { Limited } \\
\text { Distribution } \\
\text { Channels: } \\
\text { Airport.com }\end{array}$ & $\begin{array}{l}\text { Lit: Airneth (2015); } \\
\text { Grimme et al. } \\
\text { (2016); Maertens et } \\
\text { al. (2016a); Suau- } \\
\text { Sanchez et al. } \\
\text { (2016) } \\
\text { Int: Yes }\end{array}$ & $\begin{array}{l}\text { Airport.com inclusions: AFINCS itineraries are bookable } \\
\text { through the airport's dedicated website which is not a } \\
\text { common sales channel for passengers. }\end{array}$ & PIC & B_10 \\
\hline $\begin{array}{l}\text { Marketing } \\
\& \\
\text { Distribution }\end{array}$ & $\begin{array}{l}\text { Reduced } \\
\text { Ancillary } \\
\text { Sales } \\
\text { Opportunities }\end{array}$ & $\begin{array}{l}\text { Lit: N/A } \\
\text { Int: Yes }\end{array}$ & $\begin{array}{l}\text { As AFINCS itineraries are not bookable on the airline's } \\
\text { website, both partners are not able to offer their full } \\
\text { portfolio of ancillary services, at least not at the time of } \\
\text { booking. This might especially be an issue for LCCs that } \\
\text { heavily rely on ancillary revenues. }\end{array}$ & PIC & B_12 \\
\hline $\begin{array}{l}\text { Marketing } \\
\& \\
\text { Distribution }\end{array}$ & $\begin{array}{l}\text { Low Yield } \\
\text { Niche } \\
\text { Demand }\end{array}$ & $\begin{array}{l}\text { Lit: Burgwout } \\
\text { (2007); Malighetti } \\
(2016) ; \text { OAG } \\
\text { (2016); Suau- } \\
\text { Sanchez et al. } \\
\text { (2016) } \\
\text { Int: Yes }\end{array}$ & $\begin{array}{l}\text { Passengers willing to book an AFINCS itinerary will in the } \\
\text { majority of the cases sacrifice time, convenience and airline } \\
\text { responsibility in case of misconnections in exchange for } \\
\text { lower airfares. Consequently, the offering only appeals to } \\
\text { price sensitive, low yield passengers. }\end{array}$ & PIC & B_13 \\
\hline
\end{tabular}

Note: Lit $=$ Literature Review; Int $=$ Interview; N/A $=$ Not Available; F\&S $=$ Frambach and Schillewaert's determinants. 
Table 6. Identified barriers (II)

\begin{tabular}{|c|c|c|c|c|c|}
\hline Element & Barrier & $\begin{array}{l}\text { Literature / } \\
\text { Interview }\end{array}$ & Description & F\&S & ID \\
\hline $\begin{array}{l}\text { Passenger } \\
\& \\
\text { Baggage } \\
\text { Handling }\end{array}$ & $\begin{array}{l}\text { Offering an } \\
\text { Unattractive } \\
\text { Transfer } \\
\text { Product }\end{array}$ & $\begin{array}{l}\text { Lit: Choi (2016); } \\
\text { Fichert \& Klopphaus } \\
\text { (2016); Grimme et al. } \\
\text { (2016); } \\
\text { Gunnarsson (2016); } \\
\text { Havel (2016) } \\
\text { Int: Yes }\end{array}$ & $\begin{array}{l}\text { Customers are used to the traditional transfer experience } \\
\text { when connecting between airlines with an e.g. interline } \\
\text { partnership. The offered transfer experience for AFINCS } \\
\text { itineraries is less convenient and more complex which in } \\
\text { turn makes it less attractive for the passenger. }\end{array}$ & PIC & B_14 \\
\hline $\begin{array}{l}\text { Passenger } \\
\& \\
\text { Baggage } \\
\text { Handling }\end{array}$ & $\begin{array}{l}\text { Offering an } \\
\text { Unfeasible } \\
\text { Transfer } \\
\text { Product: Valid } \\
\text { Travel } \\
\text { Documents } \\
\end{array}$ & $\begin{array}{l}\text { Lit: Fichert \& } \\
\text { Klopphaus (2016); } \\
\text { Grimme (2011) } \\
\text { Int: Yes }\end{array}$ & $\begin{array}{l}\text { Passengers, in some cases, are required to clear immigration } \\
\text { before they can re-enter airside and thus valid travel } \\
\text { documents, potentially Visas, are required. Obtaining a Visa } \\
\text { not only adds costs and effort, it might also be impossible } \\
\text { for some passengers. }\end{array}$ & $\mathrm{PIC}$ & B_15 \\
\hline $\begin{array}{l}\text { Post Flight } \\
\text { Passenger } \\
\text { Servicing }\end{array}$ & $\begin{array}{l}\text { Customer } \\
\text { IROPS } \\
\text { Expectations: } \\
\text { Misconnection }\end{array}$ & $\begin{array}{l}\text { Lit: Choi (2016) } \\
\text { Int: Yes }\end{array}$ & $\begin{array}{l}\text { Although the airline is not responsible in case of } \\
\text { misconnecting passengers or bags, the passenger will still } \\
\text { consider all stakeholders including the airlines to be } \\
\text { responsible. This will lead to additional costs \& efforts in } \\
\text { handling the customer complaints and potentially has a } \\
\text { negative image on the airline brand. }\end{array}$ & $\mathrm{PIC}$ & B_16 \\
\hline Miscellaneous & $\begin{array}{l}\text { Immature } \\
\text { Concept }\end{array}$ & $\begin{array}{l}\text { Lit: N/A } \\
\text { Int: Yes }\end{array}$ & $\begin{array}{l}\text { Although AFINCSs are not new, the more recent scheme } \\
\text { introduced at London-Gatwick is still not very mature with } \\
\text { ongoing adjustments to the concept. }\end{array}$ & PIC & B_17 \\
\hline Miscellaneous & $\begin{array}{l}\text { Isolated } \\
\text { Airport } \\
\text { Adoption }\end{array}$ & $\begin{array}{l}\text { Lit: Airneth (2015); } \\
\text { Grimme et al. (2016); } \\
\text { Maertens et al. } \\
\text { (2016b); Suau- } \\
\text { Sanchez et al. (2016) } \\
\text { Int: No }\end{array}$ & $\begin{array}{l}\text { Currently only few AFINCSs are offered but, as the airline } \\
\text { industry is a network industry, the attractiveness for airlines } \\
\text { as well as the passenger would be higher if other airports } \\
\text { offered a similar or in fact the same scheme. A more } \\
\text { widespread airport adoption would for instance overcome } \\
\text { the problem of the unidirectionality of routes as passengers } \\
\text { could connect at different hubs on their in- and outbound } \\
\text { journey }\end{array}$ & PIC & B_18 \\
\hline Miscellaneous & $\begin{array}{l}\text { Limited } \\
\text { Airline } \\
\text { Awareness }\end{array}$ & $\begin{array}{l}\text { Lit: N/A } \\
\text { Int: Yes }\end{array}$ & $\begin{array}{l}\text { Although the topic of self-connectivity and AFINCSs is on } \\
\text { the radar of some airports, airline consultants and is } \\
\text { discussed at industry gatherings, it appears that not many } \\
\text { airlines are aware of the concept and its underlying } \\
\text { mechanisms. }\end{array}$ & SME & B_19 \\
\hline Miscellaneous & $\begin{array}{l}\text { Few } \\
\text { Visible } \\
\text { Adopters } \\
\text { (Airline) }\end{array}$ & $\begin{array}{l}\text { Lit: N/A } \\
\text { Int: Yes }\end{array}$ & $\begin{array}{l}\text { GatwickConnects, currently the only visible AFINCS that } \\
\text { entails an airport-airline-co-operation, was adopted by } 15 \\
\text { carriers. Although this is around } 1 / 3 \text { of all passenger airlines } \\
\text { in LGW ( } 43 \text { scheduled passenger airlines as of May 2017) it } \\
\text { is a small fraction of the overall industry. }\end{array}$ & EI & B_20 \\
\hline Miscellaneous & $\begin{array}{l}\text { Legacy } \\
\text { Business } \\
\text { Model }\end{array}$ & $\begin{array}{l}\text { Lit: N/A } \\
\text { Int: Yes }\end{array}$ & $\begin{array}{l}\text { Airlines that have already implemented traditional airline } \\
\text { partnership mechanisms such as interline or codeshares will } \\
\text { not be interested in trialing this new partnership mechanism. }\end{array}$ & $\mathrm{AC}$ & B_21 \\
\hline
\end{tabular}

Note: Lit $=$ Literature Review; Int $=$ Interview; N/A $=$ Not Available; F\&S $=$ Frambach and Schillewaert's determinants.

As described in the methodological section, the just presented 38 drivers and barriers are the input for our survey. Since the focus of our research was put on the perceived innovation characteristics, the 30 drivers and barriers (12 drivers and 18 barriers) that were considered to be perceived innovation characteristics are primarily discussed in this results section. ${ }^{3}$ Furthermore, as mentioned earlier, only the drivers and barriers with a mean score $>3.8$ are analysed and synthesised in greater detail.

The survey results reveal that only $32 \%$ of the respondents have heard of AFINCSs prior to the survey (B_19). That value further decreases to $29 \%$ if only respondents working for an airline, the potential adopters, are considered. This somewhat questions the validity of the claim made by several stakeholders (e.g. Gunnarsson (2016) or Harrison (2015)) that airlines are waking up to the potential of self-connectivity and airport-led transfer schemes. Consequently, the currently limited knowledge about the

\footnotetext{
${ }^{3}$ Note that the potential driver 'Reduced Passenger Compensation Liability" (D_11) was not addressed in the survey as this topic was deemed too sensitive due to the fact that it is not yet clear how AFINCSs would be treated by consumer protection laws.
} 
existence and the functionality of such schemes including adopters (i.e. airlines) can be considered as a key indirect barrier in the diffusion and adoption process. Nevertheless, around two-thirds of all respondents stated that their reaction to AFINCSs is positive $(21 \%)$ or slightly positive $(43 \%)$. In this regard, it is worth highlighting that the percentage of positive reactions was higher when respondents were asked at the beginning of the survey $(32 \%)$ than at the end $(21 \%)$. This may indicate that the AFINCS concept is perceived less favourable after respondents have gained a better understanding of the various potential drivers and barriers for adoption.

Table 7 presents the results for the drivers. Nine of the twelve presented potential perceived innovation characteristic drivers received a mean score of $\geq 3.8$ and thus were considered key drivers when it comes to adopting AFINCSs. The standard deviation ranged from 0.914 (D_01) to 1.356 (D_07) which shows that there was no agreement among the survey participants although the dispersion of answers was not extensive.

Offering connectivity across airline business models turned out to be the strongest driver ${ }^{4}$ (D_06-MS 4.23-SD 0.994-\#1) for adopting AFINCSs which intuitively seems logical as interline and codeshare mechanisms do not work for and with pure P2P carriers. Consequently, it can be argued that AFINCSs have a relative advantage over the codeshare and interline mechanisms as they provide a technology and operational solution for an existing problem that arises from the difference in airline business models. The second ("No Prorate Dilution" - D_12 - MS 4.23 - SD 0.994), third ("No Interline Billing Audits" - D_13 - MS 4.15 - SD 1.110) and fourth ("No Impact on Accounts Receivable Turnover" - D_14 - MS 4.02 - SD 1.062) highest rated drivers all concern partnership revenue. While prorate dilution and accounts receivable turnover implications are aspects that are frequently brought forward as potential negative facets of traditional partnership mechanisms (Holloway, 2008) it is somewhat surprising that the interline audit billings appeared that high on the list. One potential reason for this could be its observability as the interline audit efforts are not only visible but also financially quantifiable.

Not being responsible for the transfer process at the connect point received a mean score of 4.00 (D_09 - SD 1.111 - \#5) while the elimination of the passenger misconnection risk was only rated 3.70 (D_10 - SD 1.219-\#11) and thus received the second lowest score. This result came as a surprise because not being exposed to the misconnection seems like an obvious and tangible airline benefit and was also mentioned multiple times during the interviews. The open comments offered some insights into what has likely driven this rather low rating as quite a number of respondents voiced their concerns that, although the misconnection risk is technically transferred from the airlines to the airport, the passengers will still hold the airlines responsible. While these concerns are valid and rational, the recent past, namely the introduction of LCCs, has shown that passenger expectations are perfectly manageable. Anecdotes from airline managers that claimed passengers will never understand why they need to pay for bags or meals should serve as lesson.

The survey respondents overall tended to agree that the "Low Risk Trialability: Operations" (D_04-MS 3.91-SD 0.919-\#6) and "Low Risk Trialability: Costs" (D_03 - MS 3.83 - SD 0.975 - \#7) make AFINCSs interesting for airlines which, according to Frambach and Schillewaert (2002) should have a positive impact on the airlines adoption decision. Once more it can be argued that AFINCSs have a relative advantage over the

\footnotetext{
${ }^{4}$ Note that the driver "No Prorate Dilution" (D_12) received the same mean score and also showed the exact same standard deviation. The reasons for placing "Connectivity Across Business Models" (D_06) on the first rank was that the Top 2 box rating ("Agree" \& "Tend to Agree") was with $83.0 \%$ above the "No Prorate Dilution" Driver (80.9\%).
} 
codeshare and interline mechanisms that cannot be trialled by the airlines without incurring major costs and adding operational risks.

Beyond the trialability, survey participants tended to agree that airlines might be interested in AFINCSs as the participation creates limited additional costs (D_01 - MS 3.81 - SD $0.914-$ \#8). The Driver "Limited Additional Complexity" ranked last (D_02 - MS 3.57 - SD 1.087 - \#12), which seemed to have two reasons. First, similar to what was already mentioned for D_10, FSNCs have learned to manage the complexity of partnerships and thus this Driver might not be that relevant, at least for them. Second, several respondents feared that airports could develop their own, non-standardised AFINCSs which would increase the complexity for the airlines and also the passenger. One respondent aptly stated that "In extreme cases there will be as much airport facilitated schemes as there are airports".

The Driver "No Inter-Airline IT-System Integration Required" (D_08) came in ninth with a mean score of 3.81 and a standard deviation of 1.282 which indicates some disagreement among the respondents. The open comments revealed that several respondents were of the opinion that such a scheme cannot properly work without certain IT links being established. One respondent clearly stated that "IT systems are to be linked in any case" to allow passenger identification, for instance to track their true O\&D. During the interview research this topic was also brought up by one interviewee from an airline participating in GatwickConnects that claimed they had neither an overview about how many passengers were on their flights using the scheme nor on what O\&Ds passengers were travelling.

Table 7. Ranking of drivers according to the perceived innovation characteristics (PIC)

\begin{tabular}{|c|c|c|c|c|c|c|c|c|c|}
\hline Rank & ID & Driver & Underlying Statement & MS & Min & Max & SD & Mdn & IQR \\
\hline 1 & D_06 & $\begin{array}{l}\text { Connectivity Across } \\
\text { Business Models }\end{array}$ & $\begin{array}{l}\text {...airlines can connect with any } \\
\text { carrier, regardless of their } \\
\text { Business Model including LCCs. }\end{array}$ & 4.23 & 1 & 5 & 0.994 & 5 & 1 \\
\hline 2 & D_12 & $\begin{array}{l}\text { No Prorate } \\
\text { Dilution }\end{array}$ & $\begin{array}{l}\text {... airlines are not facing the risk } \\
\text { of pro-rate dilution. }\end{array}$ & 4.23 & 2 & 5 & 0.994 & 5 & 1 \\
\hline 3 & D_13 & $\begin{array}{l}\text { No Interline } \\
\text { Billing Audits }\end{array}$ & $\begin{array}{l}\text {...airlines are not required to } \\
\text { audit interline billings. }\end{array}$ & 4.15 & 1 & 5 & 1.110 & 5 & 1 \\
\hline 4 & D_14 & $\begin{array}{l}\text { No Impact on } \\
\text { Accounts Receivable } \\
\text { Turnover }\end{array}$ & $\begin{array}{l}\text {... airlines are not facing the risk } \\
\text { of cash-flow delays. }\end{array}$ & 4.02 & 2 & 5 & 1.062 & 4 & 2 \\
\hline 5 & D_09 & $\begin{array}{l}\text { No Inter-Airline } \\
\text { Transfer Process } \\
\text { Required }\end{array}$ & $\begin{array}{l}\text {... airlines are not responsible for } \\
\text { the transfer process at the } \\
\text { connect point. }\end{array}$ & 4.00 & 1 & 5 & 1.111 & 4 & 2 \\
\hline 6 & D_04 & $\begin{array}{l}\text { Low Risk } \\
\text { Trialability: } \\
\text { Operations }\end{array}$ & $\begin{array}{l}\text {...participation can be trialled } \\
\text { with low operational risks. }\end{array}$ & 3.91 & 1 & 5 & 0.919 & 4 & 1 \\
\hline 7 & D_03 & $\begin{array}{l}\text { Low Risk } \\
\text { Trialability: Costs }\end{array}$ & $\begin{array}{l}\text {...participation can be trialled } \\
\text { with low financial risks. }\end{array}$ & 3.83 & 1 & 5 & 0.975 & 4 & 2 \\
\hline 8 & D_01 & $\begin{array}{l}\text { Limited } \\
\text { Additional Costs }\end{array}$ & $\begin{array}{l}\text {...participation creates limited } \\
\text { additional costs for the airline. }\end{array}$ & 3.81 & 2 & 5 & 0.914 & 4 & 1 \\
\hline 9 & D_08 & $\begin{array}{l}\text { No Inter-Airline } \\
\text { IT System Integration } \\
\text { Required }\end{array}$ & $\begin{array}{l}\text {...airlines are not required to } \\
\text { connect their IT Systems. }\end{array}$ & 3.81 & 1 & 5 & 1.282 & 4 & 3 \\
\hline 10 & D_07 & $\begin{array}{l}\text { No Inter-Airline } \\
\text { Partnership } \\
\text { Agreement Required }\end{array}$ & $\begin{array}{l}\text {...airlines do not need } \\
\text { partnership agreements with the } \\
\text { other participating airlines. }\end{array}$ & 3.77 & 1 & 5 & 1.356 & 4 & 2 \\
\hline 11 & D_10 & $\begin{array}{l}\text { Eliminate the } \\
\text { Inter-Airline } \\
\text { Misconnection Risk }\end{array}$ & $\begin{array}{l}\text {...airlines are not responsible in } \\
\text { case of passenger } \\
\text { misconnections. }\end{array}$ & 3.70 & 1 & 5 & 1.219 & 4 & 2 \\
\hline 12 & D_02 & $\begin{array}{l}\text { Limited Additional } \\
\text { Complexity }\end{array}$ & $\begin{array}{l}\text {...participation creates limited } \\
\text { additional complexity for the } \\
\text { airline. }\end{array}$ & 3.57 & 1 & 5 & 1.087 & 4 & 1 \\
\hline
\end{tabular}

MS = Mean Score Min = Minimum $;$ Max = Maximum $;$ SD = Standard Deviation $;$ Mdn = Median; $\mathrm{IQR}=$ Interquartile Range 
Table 8 presents and ranks all 18 potential perceived innovation characteristic barriers based on the mean score of the survey participates. Results show that six of the 18 potential barriers obtained a mean score $\geq 3.8$ and thus were considered as key barriers when it comes to adopting an AFINCSs.

The customer expectation in case of misconnections received with 4.09 the highest mean score of all presented barriers (B_16-SD 1.028-\#1) which, as already discussed earlier, is rooted in the concern that passengers will expect the airlines to be responsible and that any potential dissatisfaction arising could have a detrimental effect on the airline. A few survey respondents also expressed their concerns about unclear liabilities concerning EC 261/2004", one even suspecting that "Consumer protective authorities may create barriers for the model, as misconnections would be considered to be liability of at least one of the transporters, not the airport". Interestingly this perception is the exact opposite to what was brought forward by one interviewee who suggested that airlines could be interested in AFINCSs as it exempts them from any liability in case of misconnections and resulting delays (D_11). As mentioned earlier, this driver was not included in the survey because of its sensitivity but feedback shows that any lack of legal clarity could be in fact a barrier to adoption.

The statement "I wonder if passengers save that much with this model" of one of the interviewees summarises a concern that several respondents seemed to share. The fact that non-competitive fares are perceived as a key barrier seems comprehensible as this was mentioned recurrently in the literature and multiple times during the interviews. In this regard, an interesting outcome of the survey is that the double charging of fees and taxes ranked second (B_05 - MS 4.04 - SD 0.824) while non-competitive fares due to sum-of-sectors fares ranked only $11^{\text {th }}$ (B_04 - MS 3.51 - SD 0.920). It is beyond the scope of this research to analyse whether non-competitive fares, irrespective if driven by double marginalisation or double charging of fees and taxes, are a real or just perceived characteristic of AFINCSs.

With a mean score of 3.98 (B_15 - SD 1.041) an operational driven barrier, that of requiring valid travel documents for the connection, ranked third and participants raised concerns such as "Who will check [the passengers] document at first point of origin?" or "Who pays for visa infringement fees?". It is somewhat surprising that an operational barrier was ranked that high while others, more strategically relevant barriers, for instance "All or None Partnership" (B_02 - MS 3.55 - SD 1.107-\#10), were ranked lower. One potential reason could be the fact that $68 \%$ of the respondents heard of, and learned about AFINCSs through the survey and thus an operational barrier was easier to comprehend and to agree with.

The survey respondents overall tended to agree that a barrier for the adoption of an AFINCS is the fact that connecting flights cannot be sold via the airline's website (B_09 - MS 3.91 - SD 1.088 - \#4). Not being able to distribute through the GDSs received a lower mean score (B_08 - MS 3.66 - SD 1.016 - \#8) which could indicate that GDSs are less important for the distribution of a product that primarily attracts price sensitive low yield customers. For LCCs that to the largest extent refrain from selling through the GDSs, this barrier should be largely irrelevant. Note, however, that this survey was carried out before 'Worldwide by easyJet' was launched in September 2017. This scheme in fact allows direct booking of connecting flights from the easyJet's website and proves that this barrier can be eliminated. Being able to sell an AFINCS ticket via the airline's website not only significantly increase the marketability, at the same time it also helps to overcome the lack of passenger awareness of the AFINCS product that the survey

\footnotetext{
${ }^{5}$ Regulation (EC) No 261/2004 outlines common rules on compensation and assistance to passengers in the event of denied boarding and of cancellation or long delay of flights (European Parliament, 2004).
} 
respondents rated as fifth most relevant barrier (B_07 - MS 3.87-SD 0.981). Creating the required passenger awareness is virtually impossible to achieve for the airport on its own simply because it would require them to advertise at all the major O\&Ds that can potentially be connected via their airport.

Airline partnerships in general carry the risk of self-diversion and the survey respondents tended to agree that this risk is a barrier when it comes to the adoption decision (B_03-MS 3.83 - SD 1.154-\#6). The risk of self-diversion will however be different for each potential adopter largely depending on the own, and the network of the partners present at the airport. The size of the risk can be somewhat quantified, for instance by the innovator (airport) or the potential adopter (airline), through a basic O\&D network analysis that identifies O\&Ds that the airline would serve together with the partners but also offers on its own. Alternatively, a more sophisticated approach using a QSI-based model could be employed (Suau-Sanchez et al., 2016). In case an airline directly sells AFINCS itineraries, like easyJet through their 'Worldwide by easyJet' platform, the airline can theoretically suppress any connect itinerary that creates potential self-diversion.

Table 8. Ranking of barriers according to the perceived innovation characteristics (PIC)

\begin{tabular}{|c|c|c|c|c|c|c|c|c|c|}
\hline Rank & ID & Barrier & Underlying Statement & MS & Min & Max & SD & Mdn & IQR \\
\hline 1 & B_16 & $\begin{array}{l}\text { Customer IROPS } \\
\text { Expectations: } \\
\text { Misconnection }\end{array}$ & $\begin{array}{l}\text {...in case of misconnections the } \\
\text { passenger will still expect the } \\
\text { airlines to be responsible }\end{array}$ & 4.09 & 2 & 5 & 1.028 & 4 & 2 \\
\hline 2 & B_05 & $\begin{array}{l}\text { Offering Non- } \\
\text { Competitive Fares: } \\
\text { Double Charging of } \\
\text { Fees \& Taxes }\end{array}$ & $\begin{array}{l}\text {...double-charging of fees \& } \\
\text { taxes will lead to fares that are } \\
\text { not competitive }\end{array}$ & 4.04 & 1 & 5 & 0.824 & 4 & 1 \\
\hline 3 & B_15 & $\begin{array}{l}\text { Offering an Unfeasible } \\
\text { Transfer Product: Valid } \\
\text { Travel Documents }\end{array}$ & $\begin{array}{l}\text {...the transfer process at the } \\
\text { connecting airport requires } \\
\text { valid travel documents for } \\
\text { immigration }\end{array}$ & 3.98 & 2 & 5 & 1.041 & 4 & 2 \\
\hline 4 & B_09 & $\begin{array}{l}\text { Limited Distribution } \\
\text { Channels: } \\
\text { Airline.com }\end{array}$ & $\begin{array}{l}\text {...the connecting flights cannot } \\
\text { be sold via the airline's website }\end{array}$ & 3.91 & 1 & 5 & 1.088 & 4 & 1 \\
\hline 5 & B_07 & $\begin{array}{l}\text { Lack of Passenger } \\
\text { Awareness: } \\
\text { AFINCS Product }\end{array}$ & $\begin{array}{l}\text {...the passenger awareness of } \\
\text { such schemes is limited }\end{array}$ & 3.87 & 1 & 5 & 0.981 & 4 & 2 \\
\hline 6 & B_03 & $\begin{array}{l}\text { Risk of } \\
\text { Self-Diversion }\end{array}$ & $\begin{array}{l}\text {...passengers might be diverted } \\
\text { from the own direct or } \\
\text { connecting flight (Self- } \\
\text { diversion) }\end{array}$ & 3.83 & 1 & 5 & 1.154 & 4 & 2 \\
\hline 7 & B_01 & $\begin{array}{l}\text { Incremental } \\
\text { Revenue Uncertainty }\end{array}$ & $\begin{array}{l}\text {...the actual revenue potential } \\
\text { for the airline is not yet clear }\end{array}$ & 3.68 & 2 & 5 & 0.970 & 4 & 1 \\
\hline 8 & B_08 & $\begin{array}{l}\text { Limited Distribution } \\
\text { Channels: GDS }\end{array}$ & $\begin{array}{l}\text {...the connecting flights cannot } \\
\text { be sold via the Global } \\
\text { Distribution Systems (GDS) }\end{array}$ & 3.66 & 1 & 5 & 1.016 & 4 & 1 \\
\hline 9 & B_06 & $\begin{array}{l}\text { Lack of Passenger } \\
\text { Awareness: } \\
\text { AFINCS O\&D }\end{array}$ & $\begin{array}{l}\text {...the majority of traditional } \\
\text { flight search practices will not } \\
\text { identify the connecting flights }\end{array}$ & 3.55 & 1 & 5 & 1.007 & 4 & 1 \\
\hline 10 & B_02 & $\begin{array}{l}\text { "All or None" } \\
\text { Partnership }\end{array}$ & $\begin{array}{l}\text {...the airline has no choice of } \\
\text { partners as they will connect } \\
\text { with all carriers participating }\end{array}$ & 3.55 & 1 & 5 & 1.107 & 4 & 1 \\
\hline 11 & B_04 & $\begin{array}{l}\text { Offering Non- } \\
\text { Competitive Fares: } \\
\text { Double Marginalisation }\end{array}$ & $\begin{array}{l}\text {...the sum-of-sectors fare } \\
\text { offered will not be competitive }\end{array}$ & 3.51 & 1 & 5 & 0.920 & 3 & 1 \\
\hline 12 & B_12 & $\begin{array}{l}\text { Reduced Ancillary } \\
\text { Sales Opportunities }\end{array}$ & $\begin{array}{l}\text {...the indirect distribution } \\
\text { limits the sale of ancillaries }\end{array}$ & 3.51 & 1 & 5 & 1.089 & 4 & 1 \\
\hline 13 & B_10 & $\begin{array}{l}\text { Limited Distribution } \\
\text { Channels: Airport.com }\end{array}$ & $\begin{array}{l}\text {...the connecting flights can } \\
\text { only be sold through the } \\
\text { airports booking website }\end{array}$ & 3.51 & 1 & 5 & 1.127 & 4 & 2 \\
\hline 14 & B_11 & $\begin{array}{l}\text { Increasing } \\
\text { Indirect Sales }\end{array}$ & $\begin{array}{l}\text {... selling the connecting flights } \\
\text { increases indirect sales }\end{array}$ & 3.47 & 2 & 5 & 1.007 & 3 & 1 \\
\hline 15 & B_17 & $\begin{array}{l}\text { Immature } \\
\text { Concept }\end{array}$ & $\begin{array}{l}\text {...the concept is not mature } \\
\text { enough }\end{array}$ & 3.40 & 1 & 5 & 0.816 & 3 & 1 \\
\hline 16 & B_18 & $\begin{array}{l}\text { Isolated Airport } \\
\text { Adoption }\end{array}$ & $\begin{array}{l}\text {...the scheme is not widely } \\
\text { offered by many airports }\end{array}$ & 3.32 & 1 & 5 & 1.094 & 3 & 1 \\
\hline
\end{tabular}




\begin{tabular}{|l|l|l|l|l|l|l|l|l|l|}
\hline 17 & B_13 & $\begin{array}{l}\text { Low Yield } \\
\text { Niche Demand }\end{array}$ & $\begin{array}{l}\text {..the offer is only attractive to } \\
\text { low yield price sensitive } \\
\text { passengers }\end{array}$ & 3.17 & 1 & 5 & 1.136 & 3 & 2 \\
\hline 18 & B_14 & $\begin{array}{l}\text { Offering an Unattractive } \\
\text { Transfer Product }\end{array}$ & $\begin{array}{l}\text {.the transfer process at the } \\
\text { connecting airport is not an } \\
\text { attractive offering to the } \\
\text { passenger }\end{array}$ & 2.87 & 1 & 5 & 1.104 & 3 & 2 \\
\hline
\end{tabular}

MS = Mean Score $;$ Min = Minimum; Max = Maximum $;$ SD = Standard Deviation; Mdn = Median; $\mathrm{IQR}=$ Interquartile Range

\subsection{Environmental influences and adopter characteristics.}

According to Frambach and Schillewaert (2002) the business environment of a potential adopter, and here mainly the competitive pressure and the amount of entities that have already adopted the innovation, can directly and indirectly drive or impede the innovation adoption decision.

The airline industry is highly competitive and one key factor driving this is the ongoing expansion of LCCs. As outlined in the literature review, first LCCs have begun to shift away from their pure P2P based flying (Daft \& Albers, 2015) and increasingly serve primary airports. The survey respondents tended to agree with the statement "AFINCSs could become increasingly attractive for airlines as LCCs are opening up to the idea of inter-airline network connectivity" (D_16 - MS 3.96 - SD 1.110) which indicates that the concept of AFINCSs is perceived as a potential mechanism to remain competitive in a market where inter-airline network connectivity is no longer an exclusive feature of hybrids and FSNCs. Competitive pressure does not necessarily have to be exercised from direct competitors but could also originate from other stakeholders in the air transport value chain. In case of non-connected airline networks this is already observable as first companies, for instance kiwi.com or dohop.com, have created products that exploit the revenue potential arising from non-connected airline networks. The survey respondents however did not feel that such a development increases the airlines interest in AFINCSs as the statement "Otherwise 3rd parties may develop their own business models exploiting non-connected airline networks" received the lowest mean score of all potential drivers presented (D_15 - MS 3.51 - SD 1.069).

The size, organisational structure and innovativeness of a potential adopter can also influence the adoption decision. While some of the survey findings do not directly relate to these determinants, they do concern the adopter characteristics. With a mean score of 4.11 (D_05 - SD 1.015), the survey respondents tended to agree that AFINCSs are attractive for current $\mathrm{P} 2 \mathrm{P}$ carriers as they can maintain their business model. Some literature concerning AFINCSs also hypothesises (e.g. Suau-Sanchez et al., 2016) that the schemes could be a key enabler for long-haul LCC services which would make carriers offering, or planning to offer those services, potential adopters. Among the survey respondents the statement "AFINCSs could be a key enabler for long-haul LCCs services" received a mean score of 3.57 (SD 1.162) which shows a rather low level of agreement with the statement. Whether or not this is rooted in the AFINCS concept or because respondents do not believe in the viability of long-haul LCC services cannot be answered from the survey findings.

The survey respondents somewhat tended to agree that AFINCSs are not attractive for carriers that have already implemented partnerships based on traditional mechanisms (B_21 - MS 3.72-SD 1.215) and tended to disagree with the statement "AFINCSs could replace traditional partnership mechanisms such as interline and codeshare” (MS 2.11 - SD 1.189). While this finding might not be surprising, it is worthwhile to note that 11 
of the 15 carriers participating in GatwickConnects ${ }^{6}$ have traditional partnership agreements ranging from basic interline up to joint venture agreements. Also, the standard deviation of 1.215 (B_21) indicates some level of disagreement among the respondents and the open comments suggest that several of them considered AFINCSs worthwhile also for FSNCs, for instance to participate in traffic flows they otherwise could not be part of, to offer connectivity at smaller spokes with limited potential partners or in general to connect their networks with those of the LCCs. A potential explanation why respondents felt that AFINCSs are mainly attractive for current $\mathrm{P} 2 \mathrm{P}$ carriers and not that attractive for carriers that have already implemented partnerships based on traditional mechanisms can be derived from Figure 9. ${ }^{7}$ The highest concentration of dots (marked in green) reveals that about one-third of all respondents (17) expect AFINCSs to be less complex than partnerships based on traditional basic interline agreements but then also expect them to yield less economic benefit. This could indicate that AFINCSs are mainly perceived as a complementing partnership mechanism attractive for carriers that are not willing to add the complexity of traditional partnerships mechanisms but then are still interested in generating some, albeit limited, additional economic benefit.

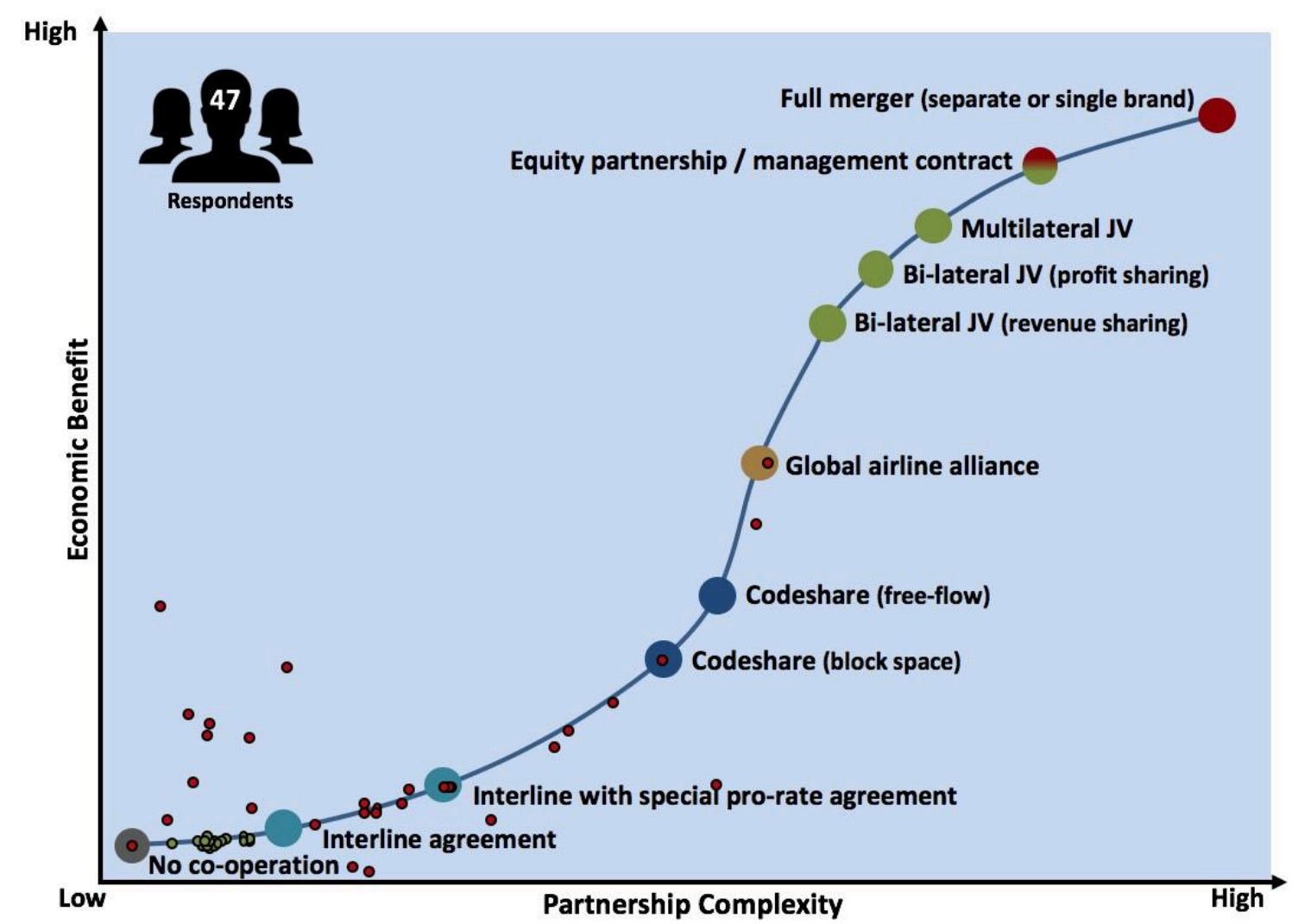

Figure 9. Benefit-complexity perception of AFINCS based on survey answers. Green dots: AFINCSs perceived less complex than interline partnerships but also less economic benefit. Source: Adapted from Seabury (2015). Results from the survey research.

\footnotetext{
${ }^{6}$ The number of carriers indicated corresponds to the moment when the analysis and survey were carried out (March-April 2017).

${ }^{7}$ Survey respondents were asked to directly point their benefit-complexity perception by clicking in the graph. The dot could be placed anywhere within the light-blue box in the graph.
} 


\section{CONCLUSIONS}

This paper has unveiled, ranked and assessed various potential drivers and barriers impacting the airline adoption of AFINCSs. Of the initial 38 drivers and barriers that were unveiled during the first research phase, 37 were included in the survey research with 30 of them relating to the perceived innovation characteristics of AFINCSs. The survey results revealed that 15 of the 30 were key drivers and barriers as the respondents' answers resulted in a MS of $\geq 3.8$. The remaining seven drivers and barriers concerned the other four sets of determinants of Frambach and Schillewaert's (2002) framework and five of them emerged as key drivers or barrier. Beyond those, three additional drivers emerged from the survey research as they were brought up by several respondents in the open comments. The in total 23 key drivers and barriers are visually depicted in Figure 10.

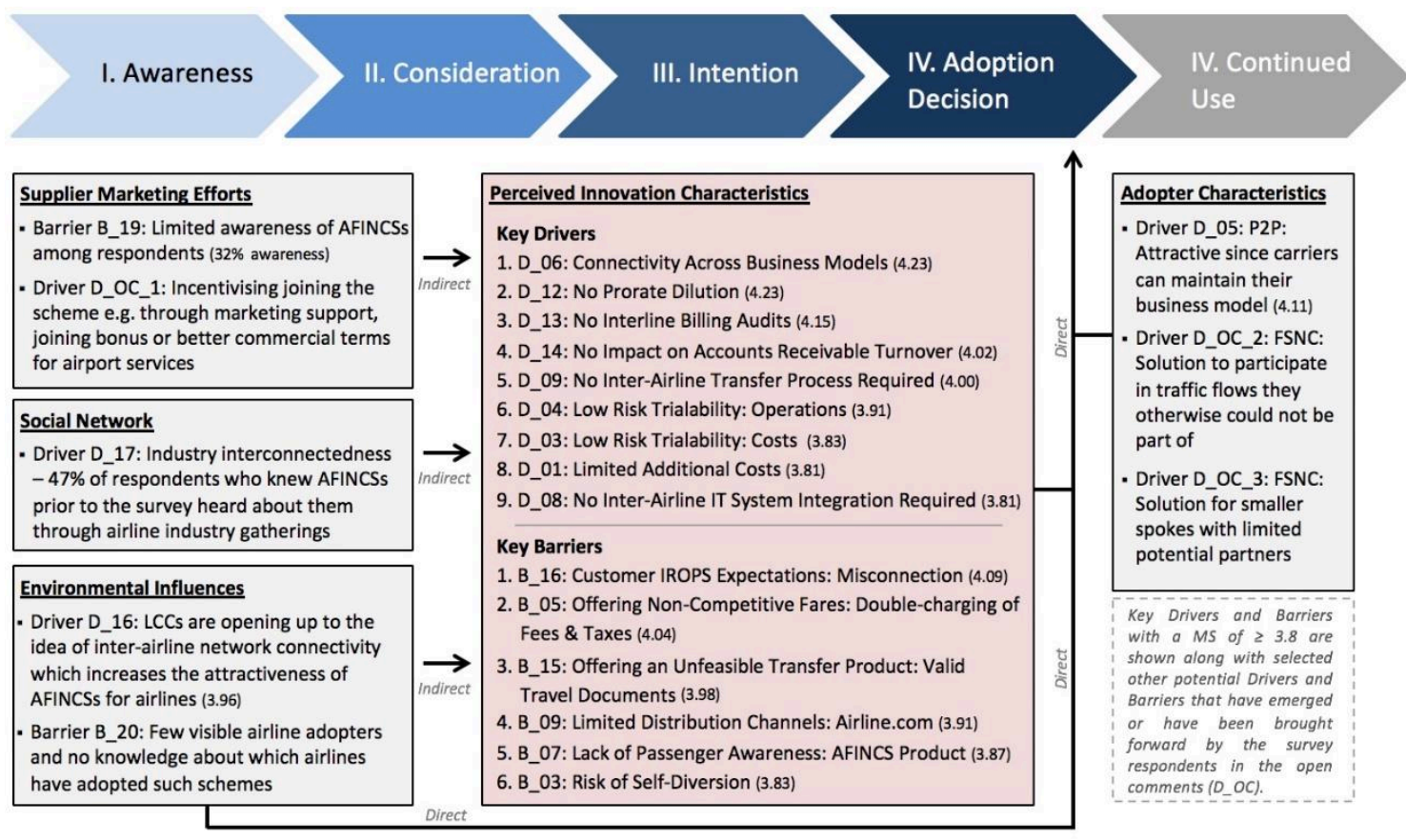

Figure 10. Key drivers and barriers for the adoption of AFINCSs.

Source: Own elaboration.

Our findings can be synthesised in three key aspects, namely limited awareness, divergent attitudes and the schemes obsolesce risk. This paper has illustrated that AFINCSs, although not entirely new, are still only at the onset of their potential diffusion. The 47 survey participants, all airline industry professionals with substantial airline partnership expertise, had mostly limited to no awareness of the AFINCS concept, its underlying mechanisms or which airlines have adopted such schemes. Awareness, as outlined in Frambach and Schillewaert's framework, is the critical first step in the organisational innovation adoption process.

The second main research finding with strategic relevance for the diffusion and airline adoption of AFINCSs is the survey participants' divergent attitudes towards the concept. Two-third of the survey participants stated a positive reaction towards AFINCSs and whilst holistically analysing and synthesising the research findings it became apparent that diverging perceptions primarily regarding the schemes' practicability, viability and economic benefit prevailed. The open comments captured through the survey research indicate that several reasons, including partial knowledge about the AFINCS concept, path dependency or personal innovativeness, were contributing factors 
to the divergent attitudes. However, it is primarily the characteristics of the innovation and how these are perceived by the potential adopters that drives a favourable or unfavourable attitude towards an innovation. Based on the collective findings, the six determinants of perceived innovation characteristics were revised and summarised in Table 10. In light of the conclusions brought forward in Table 10, the divergent attitudes towards the AFINCS innovation seem comprehensible as key determinants that have a positive relationship towards the innovation adoption decision, trialability being the only exception, were not consistently recognised by the survey participants.

Table 10. Revised perceived innovation characteristics (PIC) of AFINCSs.

\begin{tabular}{|l|l|l|}
\hline Determinants & Conclusion & Explanation \\
\hline $\begin{array}{l}\text { Relative } \\
\text { advantage }\end{array}$ & Limited Presence & $\begin{array}{l}\text { AFINCSs were perceived as complementing partnership mechanism that might be } \\
\text { adopted in specific markets (e.g. at small spokes with limited partners) or by current } \\
\text { point-to-point carriers. The concept however was not perceived as superior to the legacy } \\
\text { partnership mechanisms. }\end{array}$ \\
\hline Compatibility & Limited Presence & $\begin{array}{l}\text { Divergent opinions prevailed on whether the LCC business model is compatible with } \\
\text { network connectivity and also if LCCs require such connectivity. Overall, the research } \\
\text { findings indicated that connectivity should be under the sovereignty of the airline and not } \\
\text { the airport. }\end{array}$ \\
\hline Complexity & Limited Presence & $\begin{array}{l}\text { A surprising finding. "Participation creates limited additional complexity for the airline" } \\
\text { emerged as the lowest ranked driver. Concerns were raised that various airports could } \\
\text { develop non-standardised schemes driving complexity for airlines and passengers. }\end{array}$ \\
\hline Triability & Present & $\begin{array}{l}\text { AFINCSs can be trialled due to the limited operational risks and limited costs involved. } \\
\text { Business model continuity for current P2P carriers such as LCCs could also encourage } \\
\text { experimenting with the AFINCS concept. }\end{array}$ \\
\hline Uncertainty & Limited Presence & $\begin{array}{l}\text { Low awareness of the concept while results of AFINCSs are only visible to the adopting } \\
\text { airline (if reported by the airport). No empirical evidence exits about how beneficial } \\
\text { these schemes are for the airlines as none of the adopters has made any public claims or } \\
\text { statements. }\end{array}$ \\
$\begin{array}{l}\text { As the adoption costs of an AFINCS are limited, no uncertainty concerning the financial } \\
\text { ROI emerged. However, a high uncertainty concerning passenger expectation in case of } \\
\text { misconnections and the competitiveness of sum-of-sectors fares prevailed. }\end{array}$ \\
\hline
\end{tabular}

The third finding is related to the obsolescence risk of AFINCSs. An innovation can only add value to an airline if it solves a major problem. In relation to our results, a fundamental question arises regarding the possibility that new technology and ongoing airline business models convergence could be diminishing the capacity of AFINCSs to provide a solution to those carriers that wish to transfer passengers. In this regard, the technological advancement in the airline industry, especially when it comes to distribution capabilities, must not be ignored in the context of AFINCSs and was also brought up in the survey responses. Some participants stated that legacy technology problems that prevent partnerships across business models could soon be overcome with emerging technology solutions such as the New Distribution Capability (NDC) technology that will enable the travel industry to transform the way air products are retailed by addressing the industry's current distribution limitations, i.e., product differentiation and time-to-market, access to full and rich air content and ultimately provide a transparent shopping experience. ${ }^{8}$

Our results also suggest some avenues for future research. First, while this paper focused on the perspective of potential adopters, future contributions could focus on unveiling, ranking and assessing the actual drivers and barriers of AFINCS adopters, for instance the carriers participating in GatwickConnects or 'Worldwide by easyJet'. Second, and in relation to the obsolescence risk of the AFINCS concept, future research could look further into the impact of technological advancement and airline business models convergence, which ultimately could make the AFINCS concept obsolete. Another avenue for future research could focus on the competitiveness of ticket fares in AFINCSs.

\footnotetext{
${ }^{8}$ See IATA's NDC Program for more information: https://www.iata.org/whatwedo/airlinedistribution /nde/ Pages/default.aspx
} 
The sum-of-sectors fare price setting mechanism, as well as the double charging of fees and taxes could potentially generate non-competitive air fares. This is a concern that was confirmed by various survey respondents.

\section{ACKNOWLEDGMENTS}

The authors would like to thank the editor Anne Graham for her encouragement and patience, and the following persons for their support and input during the research: Dr Martin Müller (Star Alliance), Dr Guillaume Burghouwt (SEO Amsterdam Economics), Vittorino Capobianco (SEA - Aeroporti di Milano), David Gunnarsson (dohop.com), Timothy O'Neil-Dunne (Air Black Box), Stefan Platter (Seabury APG) and Max Reilly (Seabury APG).

\section{REFERENCES}

Airneth (2015), "Airneth report 20: The feasibility of long-haul low-cost operations", available at http://www.airneth.nl/uploads/media/Airneth_report 20_The Feasibility of _Long-Haul_Low-Cost_Operations.pdf .

Bass, F.M., (1969), “A New-product growth model for consumer durables”. Management Science 15, 215-227.

Bennett, M. (1997), "Strategic alliances in the world airline industry", International Journal of Tourism Research, 3 (3), p. 213-223.

Belobaba, P.P. \& Jain, H. (2013). “Alliance revenue management in practice: impacts of bid price sharing and dynamic valuation", Journal of Revenue and Pricing Management $12,475-488$.

Bilotkach, V. (2005), "Price competition between international airline alliances". Journal of Transport Economics and Policy 39, 167-190.

Bilotkach, V. \& Hüschelrath, K. (2010), “Antitrust immunity for airline alliances", available at: ftp://ftp.zew.de/pub/zew-docs/dp/dp10080.pdf.

Bilotkach, V. \& Hüschelrath, K. (2012), “Airline alliances and antitrust policy: The role of efficiencies", Journal of Air Transport Management, 21, p. 76-84.

Bissessur, A. \& Alamdari, F. (1998), "Factors affecting the operational success of strategic airline alliances", Transportation, 25 (4), p. 331-355.

Burghouwt, G. (2007), “Airline network development in Europe and its implications for airport planning”, Ashgate, Hampshire.

Burton J. \& Hanlon, P. (1994), “Airline alliances: Cooperating to compete?”, Journal of Air Transport Management, 1, p. 209-227. 
Breitenmoser, P., Abraham, R., Eurich, M., Mettler, T., (2013), "Why innovation in air navigation services is so difficult in Europe - A study identifying current obstacles and potential ICT enablers". Proceedings of the $21^{\text {st }}$ European Conference on Information Systems, 1-12.

Brueckner, J.K. (2006), "International Airfares in the Age of Alliances: The Effects of Codesharing and Antitrust Immunity", Review of Economics and Statistics 85, 105-118.

CAPA (2016), “Asian LCC Value Alliance establishes a new direction, using a new connectivity technology platform", available at: https://centreforaviation.com/ analysis/reports/asian-lcc-value-alliance-establishes-a-new-direction-using-a-newconnectivity-technology-platform-285916.

Capobianco, V. (2016), "The growth of the low cost airlines and the changing role of the airport in supporting transit passengers and sustaining connectivity", available at: http://www.airneth.nl/uploads/media/Presentation_Vittorino_Capobianco.pdf.

Cattaneo, M., Malighetti, P., Paleari, S., Redondi, R., (2017), "Evolution of the European network and implications for self-connection”, Journal of Air Transport Management 65, $18-25$.

Cheng, J.; Kao, L.Y.; Ying-Chao, J. (2004), “An investigation of the diffusion of online games in Taiwan: An application of Roger's diffusion of innovation theory", Journal of American Academy of Business, Cambridge, 5 (1/2), p. 439-445.

Choi, K. (2016), "What do the emerging LCC alliances mean for Asia?", vodcast, available at: http://www.centreforaviation.tv/asia-summit-15-16-nov-2016/what-do-theemerging-lcc-alliances-mean-for-asia/.

Chung, Y-S. \& Feng, C-M. (2016), "Brand relationship between global airline alliances and their member airlines", Journal of Air Transport Management 55, 222-233.

Competition Commission Singapore (2016), "Grounds of decision issued by the Competition Commission of Singapore: Application for decision by Deutsche Lufthansa AG and Singapore Airlines Limited", available at: www.ccs.gov.sg/publicregister-and-consultation/public-consultation-items/proposed-jv-between-lufthansa-andsingapore-airlines.

Cserep, K. (2016), "The future of self-connect and its implications for the Dutch aviation sector", available at: http://www.airneth.nl/uploads/media/Presentation_Kata_Cserep. pdf.

Cserep, K. (2017), "Win or lose: the airport opportunity in the growing self-conneting passenger market. ICF, available at: https://www.icf.com/resource- -s/whitepapers/2017/growing-self-connecting-passenger-market

de Wit, J. \& Zuidberg, J. (2012), "The growth limits of the low cost carrier model" Journal of Air Transport Management, 21, p. 17-23. 
Daft, J. \& Albers, S. (2015), "An empirical analysis of airline business model convergence", Journal of Air Transport Management, 46, p. 3-11.

Dennis, N. (2000), "Scheduling issues and network strategies for international airline alliances", Journal of Air Transport Management 6, 75-85.

Doganis, R. (1991), "Flying off course: The economics of international airlines", $2^{\text {nd }}$ Edition, Routledge, New York.

Doganis, R. (2010), "Flying off course: The economics of international airlines", 4" Edition, Routledge, London.

Dillman, D.; Smyth, J.D.; Christian, L.M. (2014), "Internet, phone, mail, and mixedmode surveys: The tailored design method", $4^{\text {th }}$ Edition, Wiley \& Sons, Hoboken.

Evans, N. (2001), "Collaborative strategy: An analysis of the changing world of international airline alliances", Tourism Management, 22, p. 229-243.

easyJet (2017), “easyJet announces 'Worldwide by easyJet ”, available at: https://mediacentre.easyjet.com/story/4454/easyjet-extends-worldwide-by-easyjet-toseven-airports-and-adds-new-connections-airline-partners.

Fageda, X.; Suau-Sanchez, P.; Mason, K.J. (2015), "The evolving low-cost business model: Network implications of fare bundling and connecting flights in Europe", Journal of Air Transport Management, 42, p. 289-296.

Fan, T.; Vigeant-Langlois, L.; Geissler, C.; Boler, B.; Wilmking, J. (2001), "Evolution of global airline strategic alliance and consolidation in the twenty-first century", Journal of Air Transport Management, 7, 349-360.

Fichert, F. (2013), "Multilateral interlining in deregulated air transport markets", in: Forsyth, P. et al. (Editors), Liberalization in aviation: Competition, cooperation and public policy, Ashgate, Surrey, p. 417-428.

Fichert, F. \& Klophaus, R. (2016), "Self-connecting, codesharing and hubbing among European LCCs: From point-to-point to connections?", Research in Transportation Business \& Management, 21, p. 94-98.

Frambach, R. \& Schillewaert, N. (2002), “Organizational innovation adoption: A multilevel framework of determinants and opportunities for future research", Journal of Business Research, 55, p. 163-176.

Franke, M. (2007), “Innovation: The winning formula to regain profitability in aviation?”, Journal of Air Transport Management, 13, p. 23-30.

Galang, R. (2012), "Government efficiency and international technology adoption: The spread of electronic ticketing among airlines", Journal of International Business Studies 43, 631-654. 
GatwickConnects (2015), Gatwick Connect: Commercial development, concessions, retail and media, available at: https://www.slideshare.net/ChrisBaldwin4/thedevelopment-of-gatwick-connect-48282453.

GatwickConnects (2016), "Terms and conditions", available at: https://connects.ga twickairport.com/img/booking gatwick/Gatwick_Connect_website_terms_and_conditi ons.pdf.

Ginieis, M.; Sánchez-Rebull; Campsa-Planas, F. (2012), “The academic journal literature on air transport: Analysis using systematic literature review methodology", Journal of Air Transport Management, 19, p. 31-35.

Goh, K. \& Uncles, M., (2003), "The benefits of airline global alliances: and empirical assessment of the perceptions of business travelers", Transportation Research Part A, 37, 479-497.

Grimme, W. (2008), "Low cost carrier connecting flights and interlining - A conundrum finally solved?", In: Proceedings of the 12th annual conference of the air transport research society, 06.07.2008, Athens, Greece.

Grimme, W. (2011), “The evolution of the low cost carrier business model - connections, hubbing and interlining”, available at: http://www.airneth.nl/uploads/ media/Presen tation_Wolfgang_Grimme.pdf.

Grimme, W. et al. (2016), "Virtual hubs \& self-connection for LCCs? - An overview", available at: http://elib.dlr.de/109011/1/EAC_Grimme_LCC\%20Connectivity.pdf.

Groß, S. \& Schröder, A. (2007), "Handbook of low-cost airlines: Strategies, business processes and market environment", Erich Schmitd Verlag, Berlin.

Gunnarsson, D. (2016), “Dohop company presentation”, available at: http://www.air neth.nl/uploads/media/Presentation_David_Gunnarsson.pdf.

Gunnarsson, S.V. \& Rhoades, D. L. (2001), “Airline alliance survival analysis: typology, strategy and duration", Transport Policy 8, 209-218.

Gudmundsson, S.V.; de Boer, E.R.; Lechner, C., (2002), "Integrating frequent flyer programs in multilateral airline alliances", Journal of Air Transport Management, 8, 409417

Hall W. \& Eppink, J. (1992), "Strategic alliances in the airline industry", Journal of Strategic Change, 1, p. 341-348.

Hannegan, T.F. \& Mulvey, F.P., (1995), "International airline alliances. An analysis of code-sharing's impact on airlines and consumers". Journal of Air Transport Management $2,131-137$.

Harrison, V. (2015), "Redefining airport hubs: Connectivity - the next vital piece in the industry's advancement", vodcast, available at: http://www.centreforaviation.tv/ 2015/ 
Havel, B. (2015), "Redefining airport hubs: Connectivity - the next vital piece in the industry's advancement", vodcast, available at: http://www.centreforaviation.tv/ 2015/airlines-in-transition-25-26-mar-2015/redefining-airport-hubs-connectivity-thenext-vital-piece-in-the-industrys-advancement/.

He, H-W. \& Balmer, J.M.T. (2006), “Alliance brands: building corporate brands through strategic alliances?", Journal of Brand Management 13, 242-256.

Hennemann, J. \& Malanik, J., (2010), "Cooperation and alliances-opportunity for growth". IN A. Wald, C. Fay, R. Gleich (Eds.), Introduction in Aviation Management, Lit Verlag, Berlin (2010), pp. 185-210.

Hsu, C-I. \& Shih, H-H. (2008), "Small-world network theory in the study of network connectivity and efficiency of complementary international airline alliances", Journal of Air Transport Management 14, 123-129.

Holloway, S. (2008), "Straight and level: practical airline economics", 3rd Edition, Ashgate, Hampshire.

Humphreys, B. (1994), "The implications of international codesharing", Journal of Air Transport Management, 1 (4), p. 195-207

IATA (2004), "Comments on DG competition consultation paper concerning commission regulation 1617/93, available at: http://ec.europa.eu/competition/antitrust/others/1617/ iata.pdf.

IATA (2012), “The economic benefits generated by alliances and joint ventures", available at: https://www.iata.org/whatwedo/Documents/economics/Economics\%20of\%20JVs_Jan20 12L.pdf.

Iatrou K. \& Alamdari, F. (2005), "The empirical analysis of the impact of alliances on airline operations", Journal of Air Transport Management 11, 127-134.

Iatrou K. \& Oretti M. (2007), "Airline choices for the future: From alliances to mergers", Ashgate, Hampshire.

Ito, H. \& Lee, D. (2003), "Low cost carrier growth in the U.S. airline industry: Past, present, and future", available at: https://papers.ssrn.com/sol3/ papers.cfm?abstract_id $=719741$.

Johnson, G.; Whittington, R.; Scholes, K. (2011), "Exploring corporate strategy", 9" Edition, Pearson Education, Essex.

Kapoor, K.; Dwivedi, Y.K.; Williams, M.D. (2014), "Rogers' innovation adoption attributes: a systematic review and synthesis of existing research", Information Systems Management, 31, p. 74-91. 
Kawamori, T. \& Lin, M. H. (2011), "Airline Alliances with Low Cost Carriers", Available at SSRN 1798298.

Kim, D. \& Ammeter, T. (2014), "Predicting personal information system adoption using an integrated diffusion model”, Information \& Management, 51, p. 451-464.

Krosnick, J. \& Presser, S. (2010), “Question and questionnaire design”, in: van Marsden, P. \& Wright, J. D. (Editors), Handbook of survey research, $2^{\text {nd }}$ Edition, Emerald Group Publishing, Bingley, p. 263-314.

Liang, L., James, A.D., (2009), "The low-cost carrier model in China: the adoption of a strategic innovation”, Technology Analysis \& Strategic Management 21, 129-148.

Maertens, S. Pabst, H.; Grimme, W. (2016a), “The scope for low-cost connecting services in Europe - Is self-hubbing only the beginning?", Research in Transportation Business \& Management, 21, p. 84-93.

Maertens, S.; Pabst, H.; Grimme, W. (2016b), "The development of the potential for lowcost, one-stop connecting services in Europe - From 'self-hubbing' to reliable 'low cost connecting services'?, available at: http://elib.dlr.de/104921/1/128 97 Maertens ATRS2016 LCC\%20Connect final copyright-checked.pdf.

Malighetti, P.; Paleari, S.; Redondi, R. (2008), "Connectivity of the European airport network: Self-help hubbing" and business implications", Journal of Air Transport Management, 14, p. 53-65.

Min, H. \& Joo, S-J. (2016), “A comparative performance analysis of airline strategic alliances using data envelopment analysis", Journal of Air Transport Management 52, 99-110.

Moore M., Harley J. (2008) Innovations in Governance. Public Management Review 10, 3-20.

Morandi, V.; Malighetti, P.; Paleari., S.; Redondi., R. (2015), "Codesharing agreements by low-cost carriers: An explorative analysis", Journal of Air Transport Management, 42, p. 184-191.

Morrish, S.C. \& Hamilton, R.T., (2002), “Airline alliances-who benefits?”, Journal of Air Transport Management 8, 401-407.

OAG (2016), "Self-Connection: The rise and roadblocks of a growing travel booking strategy", available at: https://cdn2.hubspot.net/hubfs/490937/Free_Reports/Self_Conn ection/Self-Connection-Survey.pdf.

Oum T. \& Park, J. (1997), "Airline alliances: Current status, policy issues, and future directions", Journal of Air Transport Management, 3 (3), p. 133-144.

Oum, T.; Park, J.H.; Zhang. A. (2000), "Globalization and strategic alliances: The case of the airline industry", Emerald Group Publishing, London. 
Oum, T.; Yu, C.; Zhang, A. (2001), "Global airline aalliances: international regulatory issues", Journal of Air Transport Management 7, 57-62.

Park, J-H. (1997), "The effects of airline alliances on markets and economic welfare" Transportation Research Part E 33, 181-195.

Pels, E. (2001), “A note on airline alliances”, Journal of Air Transport Management, 7, p. 3-7.

Philips, L. (1987), "Air carrier activity at major hub airports and changing interline practices in the United States", Transportation Research Part A, 21A (3), p. 215-221.

Rogers, E. M. (1963). The adoption process: Part I. Journal of Extension 1, 16-22.

Rogers, E. (2003), "Diffusion of innovations”, $5^{\text {th }}$ Edition, Free Press, New York.

Saunders, M.; Lewis, P.; Thornhill, A. (2009), "Research methods for business students", $5^{\text {th }}$ Edition, Pearson Education, Essex.

Seabury (2015), "Matchmaking for success: Increasing commercial benefits through airline partnerships", unpublished report.

Segerstedt, A., Grote, U. (2016), "Increasing adoption of voluntary carbon offsets among tourists", Journal of Sustainable Tourism 24, 1541-1554.

Stamp, J. (2016), "What do the emerging LCC alliances mean for Asia?", vodcast, available at: http://www.centreforaviation.tv/asia-summit-15-16-nov-2016/what-do-theemerging-lcc-alliances-mean-for-asia/.

Steer Davies Gleave (2007), "Competition impact of airline code-share agreements", available at: http://ec.europa.eu/competition/sectors/transport/reports/airlinecode share.pdf.

Suau-Sanchez, P.; Voltes-Dorta, A.; Rodríguez-Déniz, H. (2016), "Measuring the potential for self-connectivity in global air transport markets: Implications for airports and airlines", Journal of Air Transport Management, 57, p. 70-82.

Suau-Sanchez, P.; Voltes-Dorta, A., Rodríguez-Déniz, H. (2017), "An assessment of the potential for self-connectivity at European airports in holiday markets", Tourism Management, 62, p. 54-64.

Tiernan, S.; Rhoades, D.L.; Waguespack, B., (2008) “Airline service quality: Exploratory analysis of consumer perceptions and operational performance in the USA and EU", Managing Service Quality: An International Journal 18, 212-224.

Tretheway \& Oum (1992), Airline Economics: Foundations for Strategy and Policy. Vancouver: Center for Transportation Studies, University of British Columbia. 
Tretheway, M. \& Waters, W. (1998), "Reregulation of the airline industry: Could price cap regulation play a role?”, Journal of Air Transport Management, 4, p. 47-53.

Vinod, B. (2005), "Practice Papers: Alliance revenue management", Journal of Revenue and Pricing Management 4, 66-82.

Walulik, J. (2016), "At the core of airline foreign investment restrictions: A study of 121 countries", Transport Policy, 49, p. 234-251.

Wassmer, U., Meschi, P-X., (2011), "The effect of code-sharing alliance formations and terminations on firm value: The role of co-specialization and scope extension", Journal of Air Transport Management 17, 305-308.

Whalen, W. T. (2007): 'A Panel Data Analysis of Code Sharing, Antitrust Immunity and

Open Skies Treaties in International Aviation Markets', Review of Industrial Organization, 30, 39-61.

Weber, K. (2005), “Travelers' perceptions of airline alliance benefits and performance", Journal of Travel Research 43, 257-265.

Wu, C-L.; Lee, A., (2014), "The impact of airline alliance terminal co-location on airport operations and terminal development" Journal of Air Transport Management 36, 69-77.

Yin, R. (2014), "Case study research: Design and methods", 5 ${ }^{\text {th }}$ Edition, Sage Publications, Thousand Oaks.

Zeigler, P., Pagliari, R., Suau-Sanchez, P., Malighetti, P., Redondi, R. (2017), "Low-cost carrier entry at small European airports: Low-cost carrier effects on network connectivity and self-transfer potential", Journal of Transport Geography 60, 68-79. 


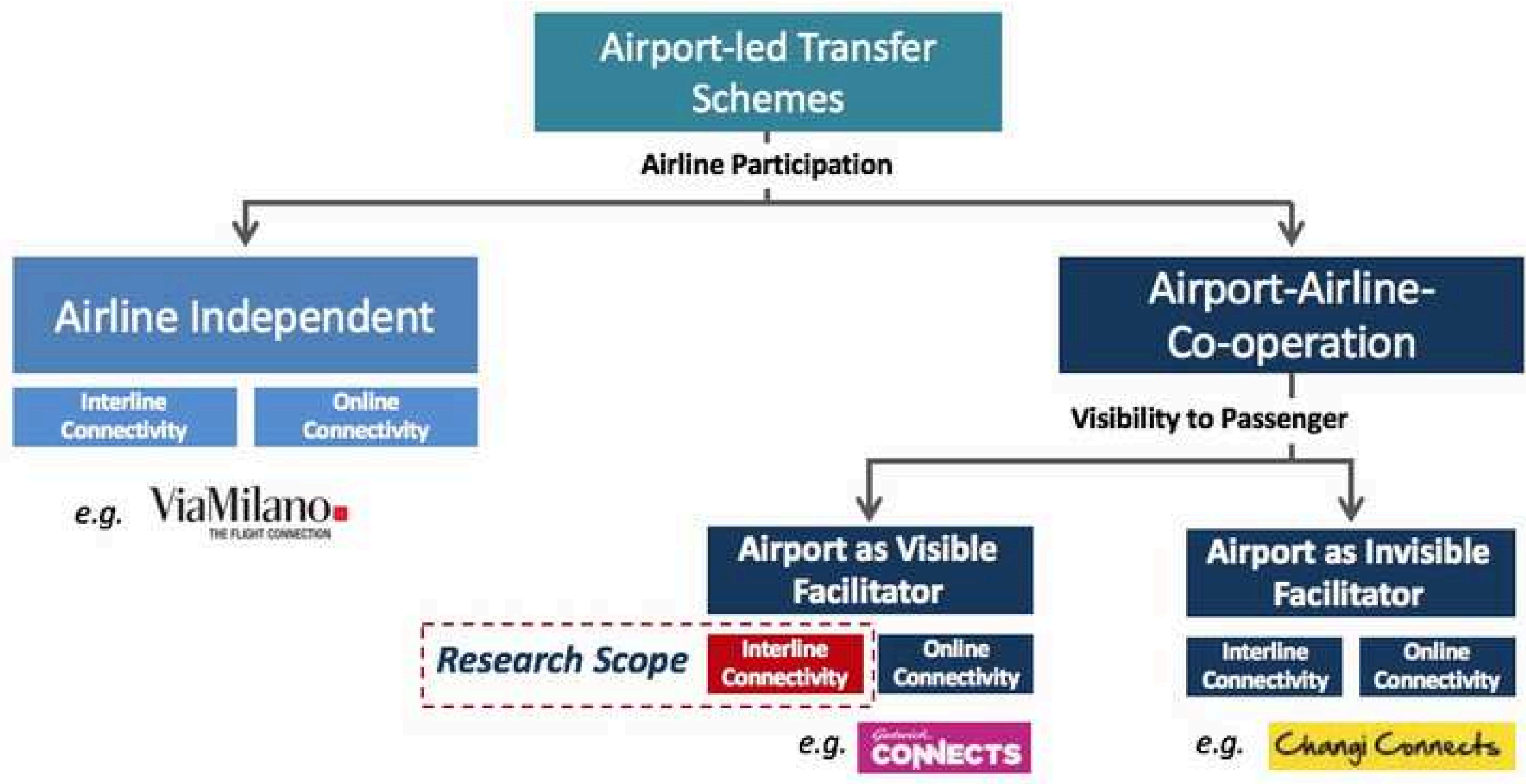

\section{Definition:}

Online Connectivity: Connection between two flights operated by the same carrier Interline Connectivity: Connection between two flights operated by different carriers 


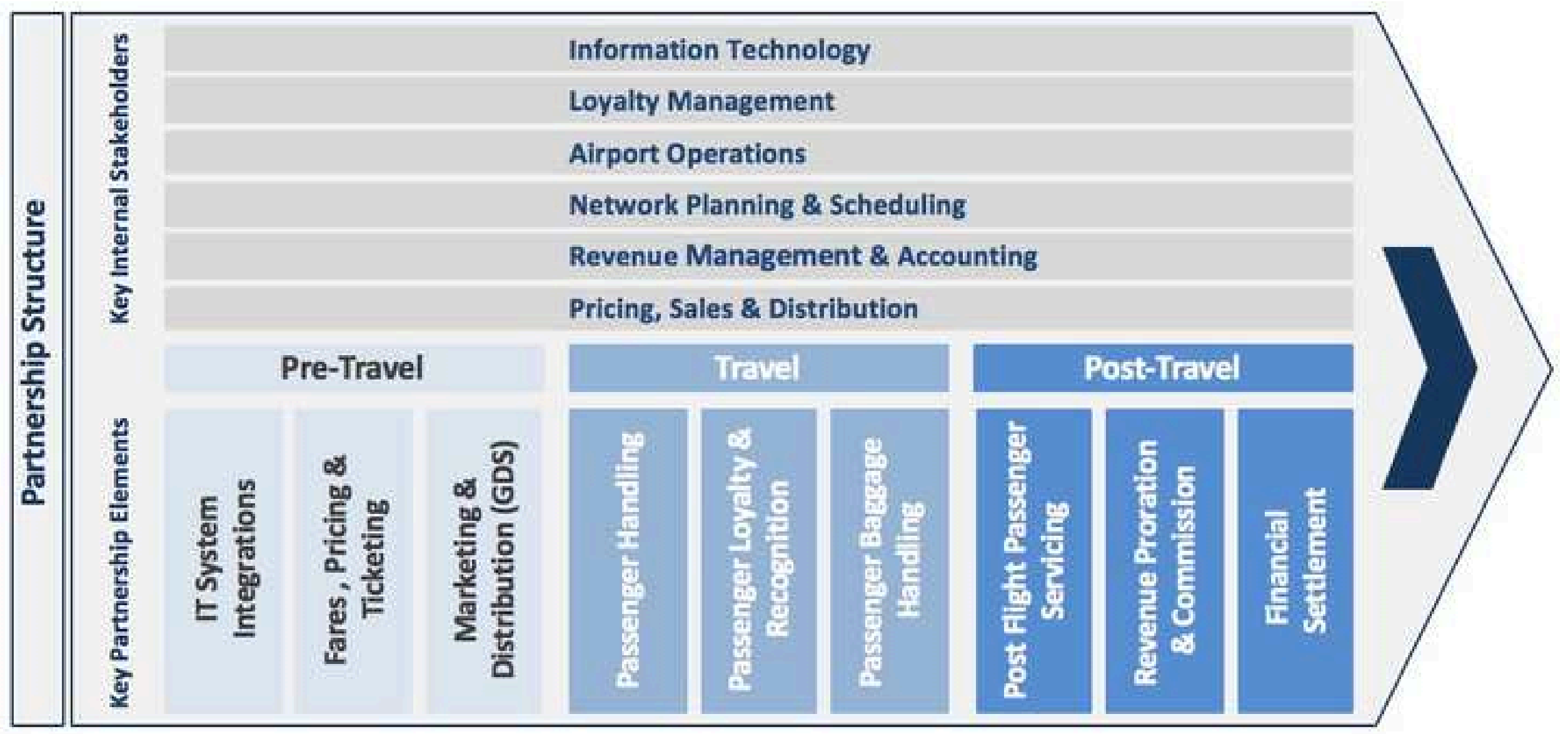

\section{Information Technology}

ment 


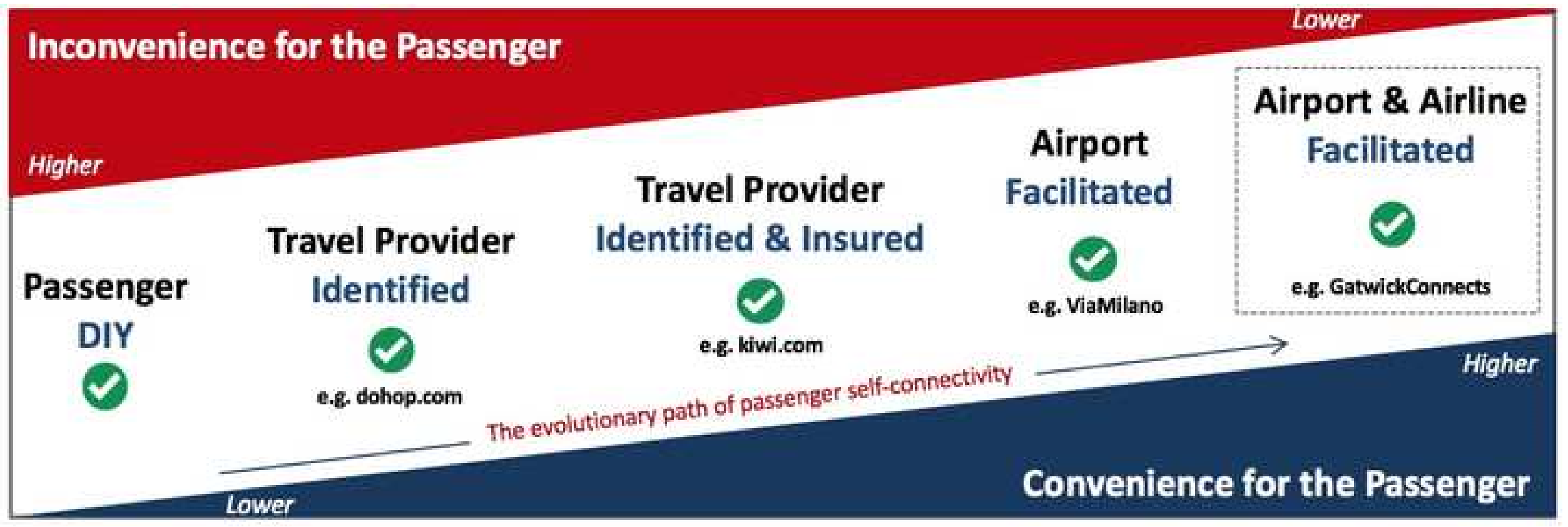




\begin{tabular}{|c|c|c|c|c|c|}
\hline & 196efill & (4) Cologne Bonn Connect & ViaMilanos & $\begin{array}{c}\text { Changi Connects } \\
\text { FMarre }\end{array}$ & CONHECTS \\
\hline Launch Year & 2006 & 2007 & 2011 & 2012 & 2013 \\
\hline $\begin{array}{l}\text { Airport-Airline } \\
\text { Co-operation }\end{array}$ & No & Yes & No & Yes & Yes \\
\hline Airlines Included & $\begin{array}{l}\text { All @ the } \\
3 \text { Berlin airports }\end{array}$ & $\begin{array}{l}2 \text { Germanwings } \\
\text { \& Tuifly }\end{array}$ & All @MXP & Scoot \& Tigerair & 15 \\
\hline Distribution & Dedicated website & Dedicated website & $\begin{array}{l}\text { Dedicated website } \\
\text { \& GDS (pop-up*) }\end{array}$ & $\begin{array}{l}\text { airline.com } \\
\text { (Scoot \& Tiger) }\end{array}$ & $\begin{array}{l}\text { Dedicated website** } \\
\text { skyscanner.com } \\
\text { dohop.com }\end{array}$ \\
\hline $\begin{array}{l}\text { \# of ticket booking / } \\
\text { financial transactions }\end{array}$ & $2 / 2$ & $1 / 1$ & $2 / 2$ & $1 / 1$ & 年 \\
\hline $\begin{array}{l}\text { Passenger Usage } \\
\text { Fee (per connection) }\end{array}$ & None & None & None & approx. $€ 13.80$ & approx. $€ 14.80$ \\
\hline $\begin{array}{l}\text { Passenger / } \\
\text { Bagzage connection }\end{array}$ & $\begin{array}{l}\text { Via landside } \\
\text { Via landside }\end{array}$ & $\begin{array}{l}\text { Via landside } \\
\text { Airside bag-drop }\end{array}$ & $\begin{array}{l}\text { Via landside foast troch) } \\
\text { Airside bag-drop }\end{array}$ & $\begin{array}{l}\text { Remain airside } \\
\text { Through-checked }\end{array}$ & $\begin{array}{l}\text { Via landside (fost trock) } \\
\text { Alrside bag-drop }\end{array}$ \\
\hline Insurance & $\begin{array}{l}\text { Optional } \\
\text { (c 8.00) }\end{array}$ & $\begin{array}{l}\text { Optional } \\
\text { (C7.50) }\end{array}$ & Included & Included & Included \\
\hline Comments & $\begin{array}{l}\text { - Essentially just a } \\
\text { search-engine to } \\
\text { Identify filghts via } \\
\text { Berlin } \\
\text { Ceased operations } \\
\text { approx-2010 (last } \\
\text { mentioned in Annual } \\
\text { Report 2009) } \\
\text { Shuttle between the } \\
\text { Berlin airports (fee) }\end{array}$ & $\begin{array}{l}\text { Connections between } \\
\text { Germanwings \& Tuifly } \\
\text { - Operational platform } \\
\text { also used for German- } \\
\text { wings online transfers } \\
\text { ('Smart Connect') } \\
\text { Ceased operations in } \\
2010 \text { (Tulfly ceased LCC } \\
\text { operations) } \\
\text { - New attempt in } 2018\end{array}$ & $\begin{array}{l}\text { - Booking functionality } \\
\text { added in } 2012 \\
\text { To quality a passenger } \\
\text { needs have two tickets } \\
\text { connecting at MXP } \\
\text { (restrictions) } \\
\text { - Passenger can apply } \\
\text { post ticket purchase for } \\
\text { the scheme }\end{array}$ & $\begin{array}{l}\text { - Current status unclear } \\
\text { - Changi Connects was } \\
\text { the platform for 'Scoot } \\
\text { Through' \& Tiger } \\
\text { Connect' } \\
\text { - Recently Singapore } \\
\text { Airtines \& Silledit were } \\
\text { added to 'Scoot } \\
\text { Through' \& 'Tiger } \\
\text { Connect' }\end{array}$ & $\begin{array}{l}\text { - Airline participation on } \\
\text { opt-in base } \\
\text { - Booking functionality } \\
\text { including insurance for } \\
\text { misconnection added } \\
\text { in } 2015 \\
\text { (GatwickConnectst) } \\
\text { Tickets must be } \\
\text { purchased through } \\
\text { dedicated website }\end{array}$ \\
\hline
\end{tabular}

-Amadeus \& Travelport: additional wizard with pop-up function thus not shown in traditional GDS display - " not all carriers are bookable through the dedicated boaking website. 

(2.) Introductory Section to AFINCSs 


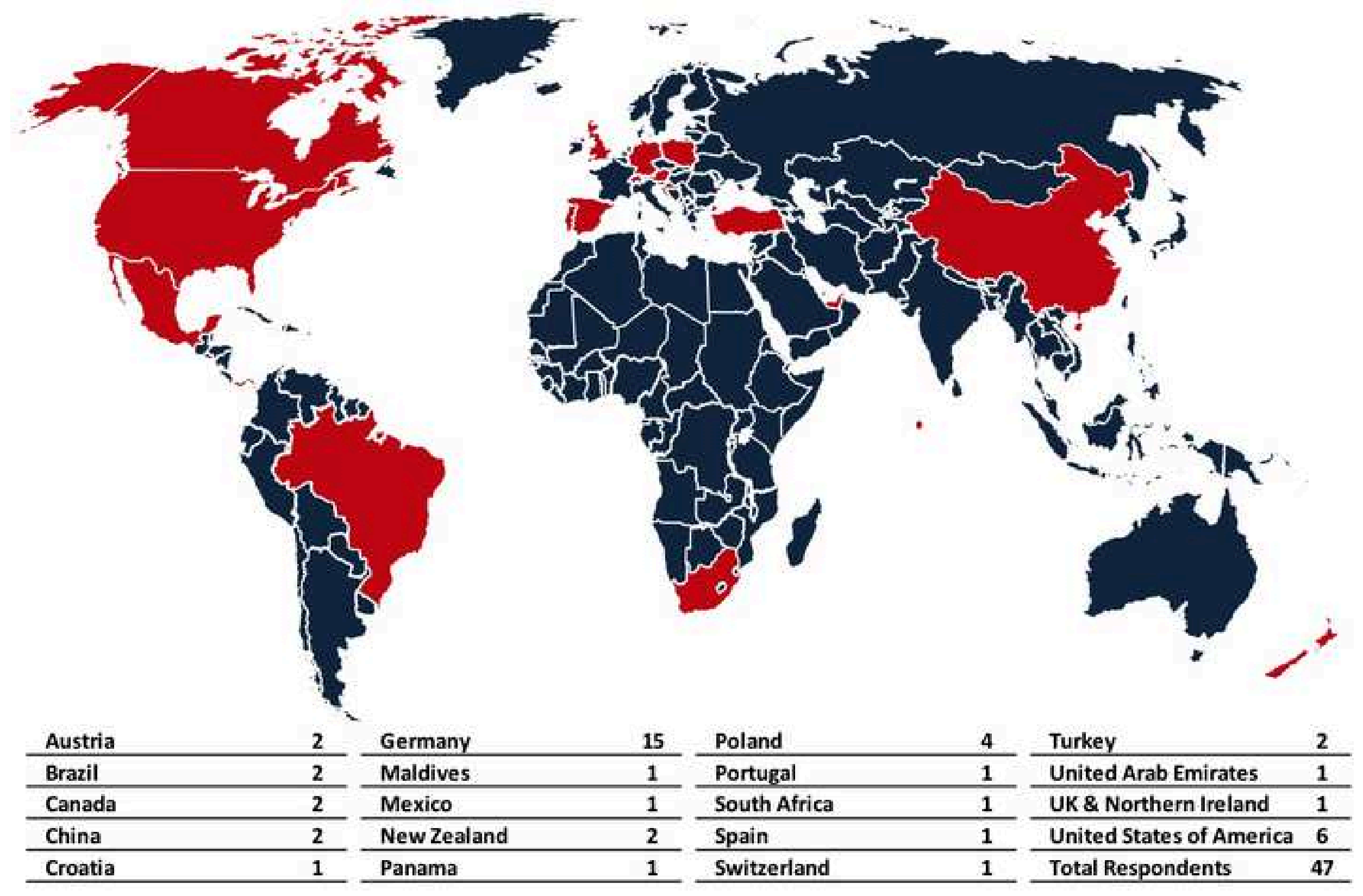




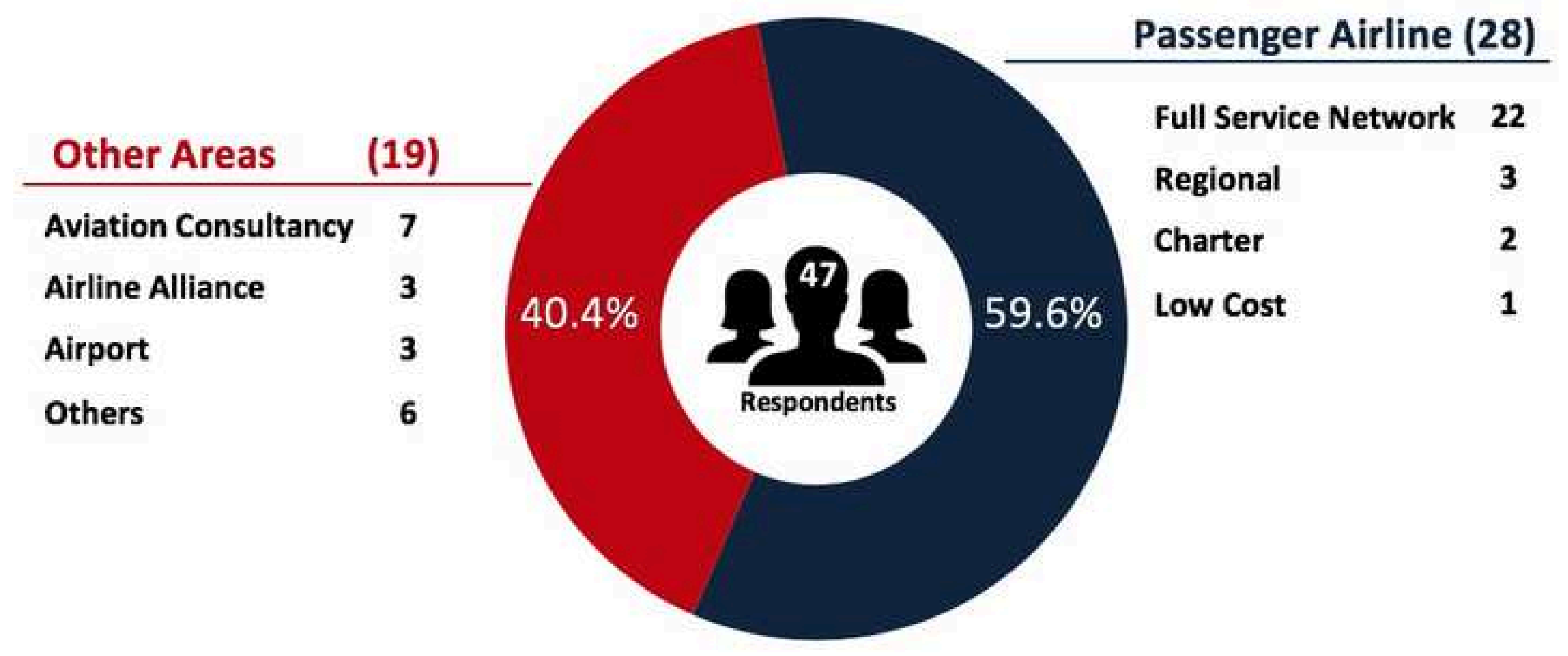




\section{Awareness}

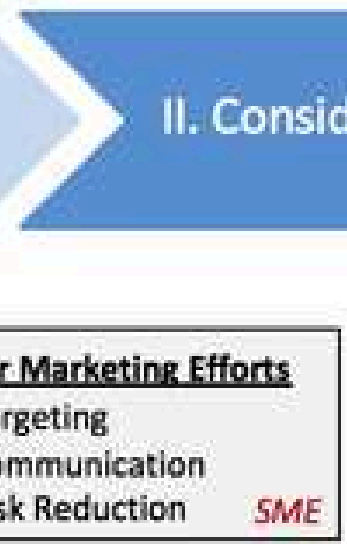

\section{Social Network}

- Interconnectedness/ Network Participation

\begin{tabular}{|l|l|}
\hline Supplier Marketing Efforts \\
\hline . Targeting \\
- Risk Reduction SME \\
\hline
\end{tabular}

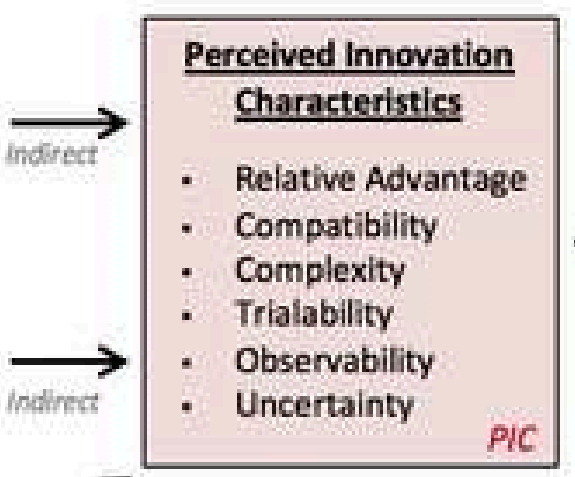

Direct

IV. Adoption

Decision

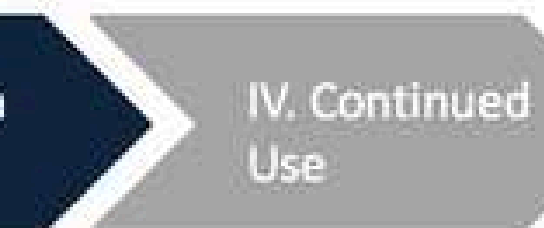

\begin{tabular}{|l|}
\hline Environmental Influences \\
\hline . Network Externalities \\
\hline
\end{tabular}
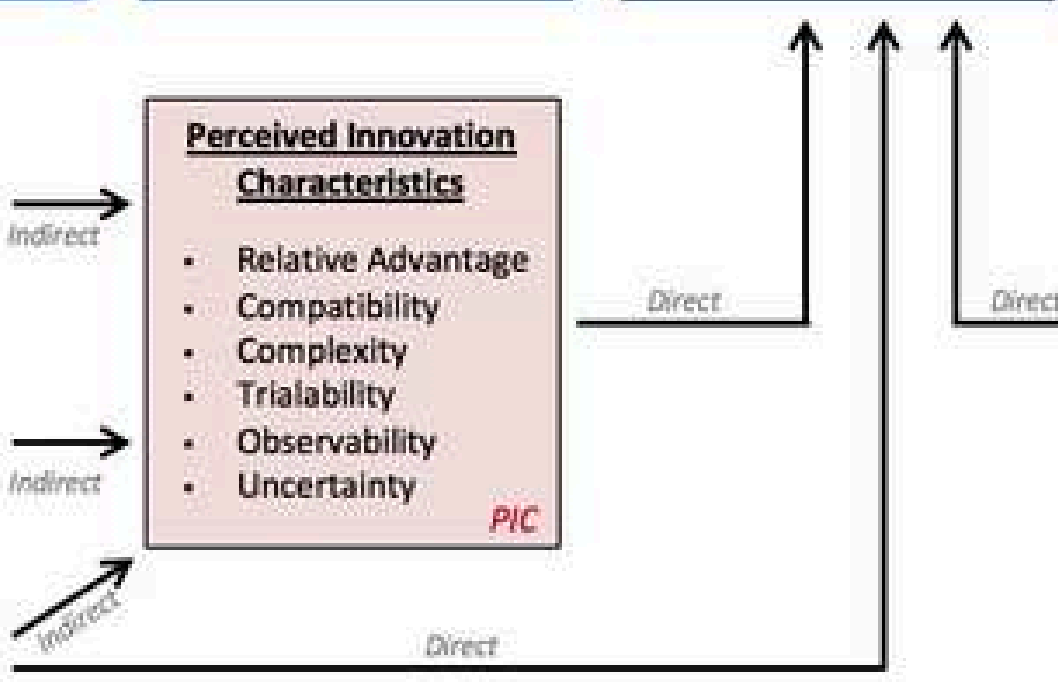

\section{Adopter Characteristics}

- Size

- Structure

Organisationsal

Innovativeness or

Strategic Posture

$A C$ 


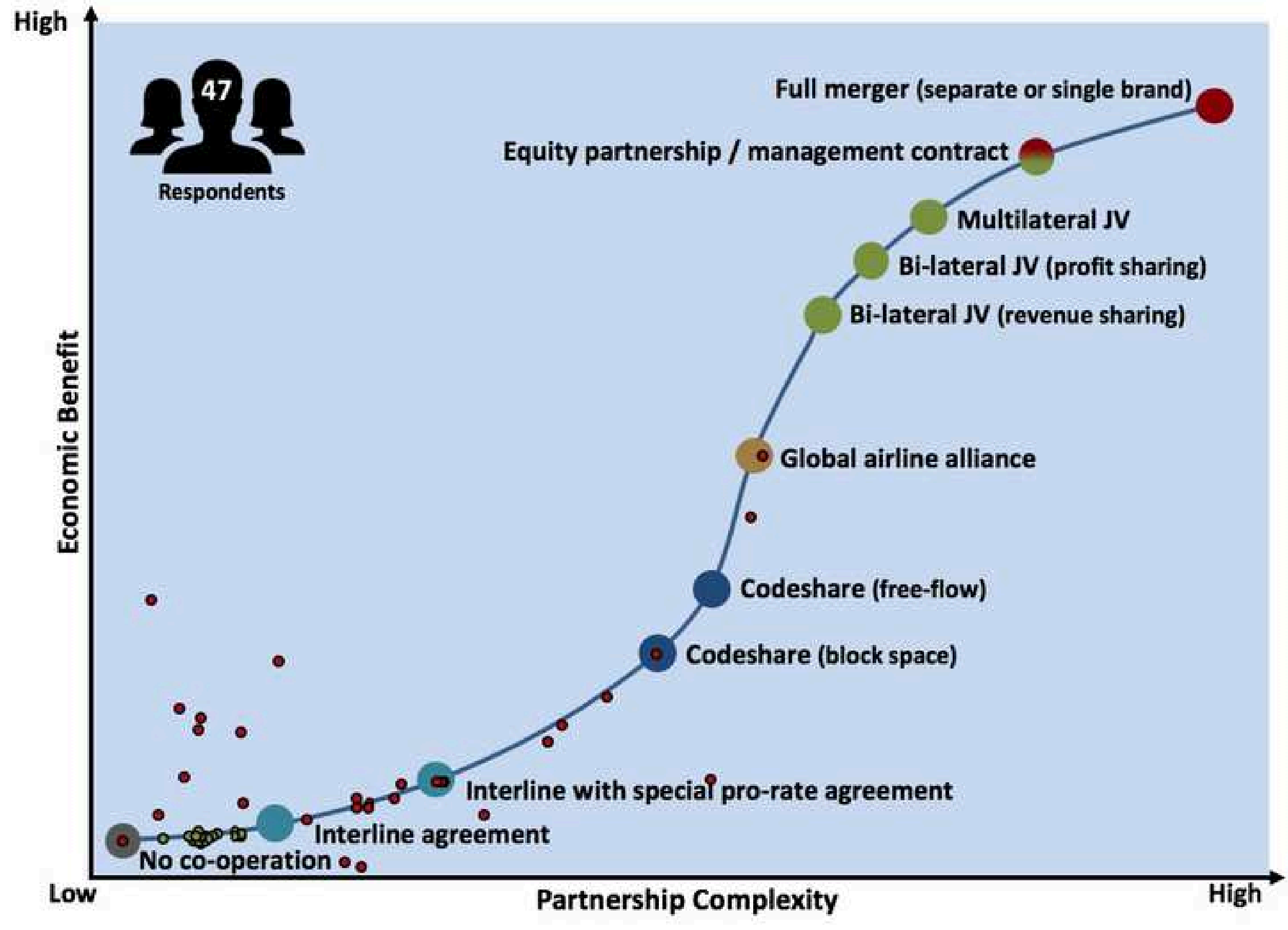

Full merger (separate or single brand)

Multilateral JV Bi-lateral JV (profit sharing) Bi-lateral JV (revenue sharing) Interline with speciai pro-rate agreement Partnership Complexity 


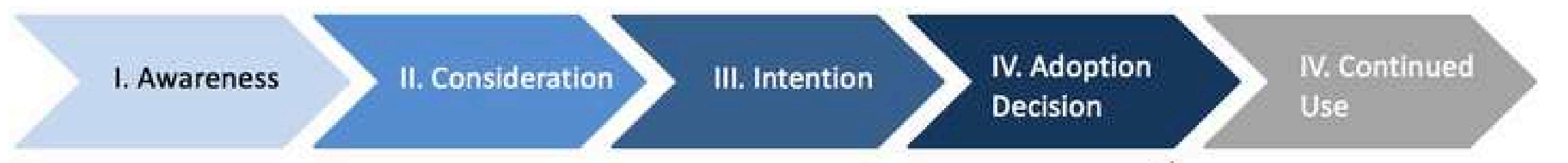

Supplier Marketing Efforts
- Barrier B_19: Limited awareness of AFINCSs
among respondents (32\% awareness)
- Driver D_OC_1: Incentivising joining the
scheme e.g. through marketing support,
joining bonus or better commercial terms
for airport services

\section{Social Network}

- Driver D_17: industry interconnectedness $-47 \%$ of respondents who knew AFINCSs prior to the survey heard about them through airline industry gatherings

\section{Environmental Influences}

- Driver D_16: LCCS are opening up to the idea of inter-airline network connectivity which increases the attractiveness of AFINCSs for airlines (3.96)

- Barrier B_20: Few visible airline adopters and no knowledge about which airlines have adopted such schemes

\section{Perceived Innovation Characteristics}

\section{Key Drivers}

\section{$\rightarrow$}

indivect

1. D_06: Connectivity Across Business Models (4.23)

2. D_12: No Prorate Dilution (4.23)

3. D_13: No Interline Billing Audits (4.15)

4. D_14: No Impact on Accounts Recelvable Turnover (4.02)

5. 0_09: No Inter-Airline Transfer Process Required (4.00)

6. D_04: Low Risk Trialability: Operations (3.91)

7. D_03: Low Risk Trialability: Costs (3.83)

8. D_01: Limited Additional Costs (3.81)

9. D_OB: No Inter-Airline IT System Integration Required (3.81)

\section{Key Barriers}

1. 8_16: Customer IROPS Expectations: Misconnection (4.09)

2. 8_05: Offering Non-Competitive Fares: Double-charging of Fees \& Taxes $(4.04)$

3. B_15: Offering an Unfeasible Transfer Product: Valid

Travel Documents (3.98)

4. B_09: Uimited Distribution Channels: Airline.com (3.91)

5. B_07: Lack of Passenger Awareness: AFINCS Product (3.87)

6. 8_03: Risk of Self-Diversion (3.83)

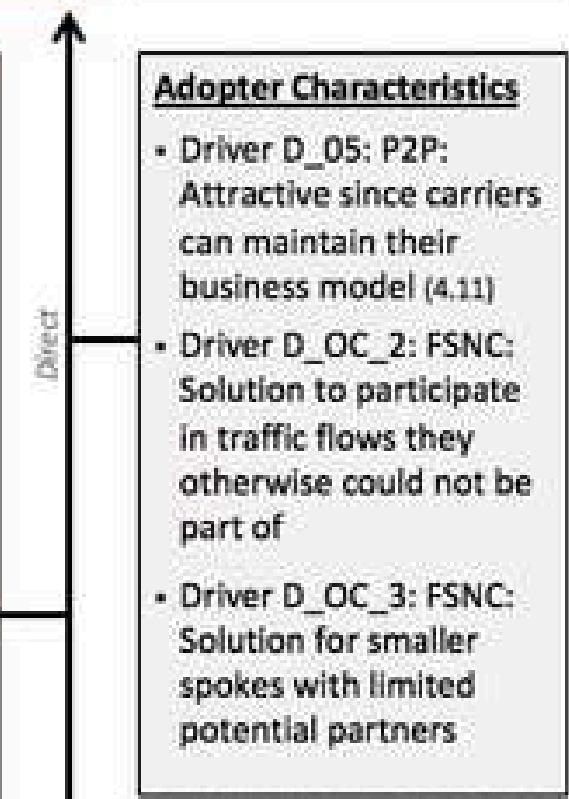

Key Drivers and Bamiers with a MS of 23.8 are shown along with seiected ather potential Drivers and Barriers that have emerged or have been brought forward by the survey respondents in the ogen comments (D_OC). 


\section{Challenging the interline and codeshare legacy: Drivers and barriers for airline adoption of airport facilitated inter-airline network connectivity schemes}

Never, Jan

Elsevier

Never J, Suau-Sanchez P. (2020) Challenging the interline and codeshare legacy: Drivers and barriers for airline adoption of airport facilitated inter-airline network connectivity schemes.

Research in Transportation Economics, Volume 79, March 2020, Article number 100736

https://doi.org/10.1016/j.retrec.2019.100736

Downloaded from Cranfield Library Services E-Repository 